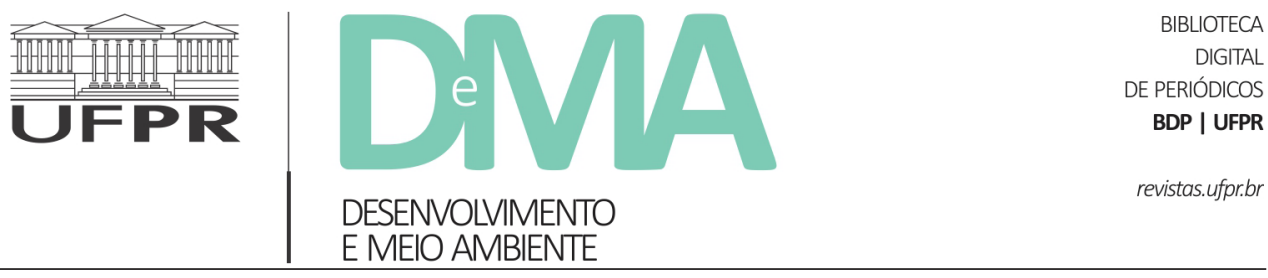

\title{
Ecocídio nos Cerrados: agronegócio, espoliação das águas e contaminação por agrotóxicos
}

\section{Ecocide in the Cerrados (Brazilian Savanna): agribusiness, water spoliation and pesticide contamination}

\author{
Daniela da Silva EGGER ${ }^{1}$, Raquel Maria RIGOTTO²*, Francco Antonio Neri de Souza e LIMA³, André \\ Monteiro COSTA ${ }^{4}$, Ada Cristina Pontes AGUIAR ${ }^{2,5}$ \\ ${ }^{1}$ Gemap - Grupo de Estudos sobre Mudanças Sociais, Agronegócio e Políticas Públicas, Programa de Pós-Graduação de Ciências Sociais em \\ Desenvolvimento, Agricultura e Sociedade (Cpda), Universidade Federal Rural do Rio de Janeiro (UFRRJ), Seropédica, RJ, Brasil. \\ ${ }^{2}$ Núcleo Tramas - Trabalho, Meio Ambiente e Saúde, Pós-Graduação em Saúde Pública, Universidade Federal do Ceará (UFC), Fortaleza, \\ CE, Brasil. \\ ${ }^{3}$ Escola Nacional de Saúde Pública Sérgio Arouca, Fundação Oswaldo Cruz (Fiocruz), Rio de Janeiro, RJ, Brasil. \\ ${ }^{4}$ Laboratório de Saúde Ambiente e Trabalho (Lasat), Fundação Oswaldo Cruz (Fiocruz), Recife, PE, Brasil. \\ ${ }^{5}$ Faculdade de Medicina, Universidade Federal do Cariri (UFCA), Juazeiro do Norte, CE, Brasil. \\ *E-mail de contato: raquelrigotto@gmail.com
}

Artigo recebido em 31 de agosto de 2020, versão final aceita em 3 de março de 2021, publicado em 30 de junho de 2021.

RESUMO: $\quad$ Com 65 milhões de anos, os Cerrados constituem-se de intensa biodiversidade, que tem relação com sua abundância em águas e a dinâmica do ciclo hidrológico, perenizando rios de seis das oito regiões hidrográficas do país e transbordando suas águas para outros países do subcontinente americano. O bioma abriga diversos povos e comunidades tradicionais que constituíram modos de vida e saberes ancestrais. Nas últimas décadas, o Estado vem implementando nesse território políticas de desenvolvimento subordinadas ao neoextrativismo e à acumulação por espoliação de grandes corporações. Assim, os Cerrados têm sido invadidos pela expansão do agronegócio, que resultam em intensa conflitividade no bioma, além de tentar exterminar os modos de vida dos diferentes povos. Foram reunidas informações e análises para caracterizar o Ecocídio dos Cerrados, onde mais de 110 milhões de hectares do bioma estão ocupados pelo agronegócio - com área plantada para produzir $75 \%$ das commodities soja-cana-milho-algodão cultivadas no Brasil e as áreas de pastagem destinadas à produção de carne bovina. Isso implica na destruição de $52 \%$ da vegetação nativa e no consumo de $91,8 \%$ das águas superficiais e subterrâneas usadas na irrigação por pivôs centrais, resultando na migração de nascentes, na interrupção dos fluxos dos rios e na redução dos volumes dos aquíferos, como se aprofunda na análise

Desenvolv. e Meio Ambiente usa uma Licença Creative Commons - Atribuição-NãoComercial-SemDerivações 4.0 Internacional 16 
dos conflitos em curso no oeste da Bahia e na bacia dos rios Formoso e Javaés/TO. A isso, somam-se os impactos do uso intensivo de agrotóxicos sobre todas as formas de vida - são mais de 600 milhões de litros de venenos anualmente, concentrando $73,5 \%$ do total de agrotóxicos consumidos no país em 2018 , sobre a saúde humana resulta em taxas de intoxicação exógena e câncer infanto-juvenil nos Cerrados maiores que as médias nacionais. Os Cerrados caracterizam-se como zona de sacrifício do desenvolvimento brasileiro, em que natureza e povos são saqueados para garantir a acumulação de poucos, num processo de Ecocídio que é o produto moderno-colonial racista no bioma.

Palavras-chave: Cerrados; agronegócio; povos e comunidades tradicionais; espoliação das águas; contaminação por agrotóxicos.

ABSTRACT: At 65 million years old, the Cerrados biome is constituted of wide biodiversity related to its water's abundance and hydrological cycle's dynamics, perpetuating rivers in six of eight Brazilian river basins and overflowing its waters to other countries of the South American subcontinent. The biome hosts a diverse set of traditional communities that constituted livelihoods based on their ancestral knowledge. In recent decades, the Brazilian State has been implementing development policies in these territories that are subordinated to neo-extractivism and accumulation by the plunder of large corporations. Thus, the Cerrados biome was invaded by the agribusiness accelerated expansion that results in intense conflicts, threatening or refraining the livelihood of different populations. Information and analysis were gathered to characterize the Cerrados biome Ecocide, where around 120 million hectares are destined to produce $75 \%$ of Brazilian commodities soy-cane-corn-cotton, which destroyed $52 \%$ of the native vegetation, and consumed $91.8 \%$ of surface water and groundwater in pivot irrigation systems, resulting in the migration of springs, the interruption of river flows and the reduction of aquifer volumes, as observed in the analysis of ongoing conflicts in western Bahia and the basin of the Formoso and Javaés rivers, in Tocantins State. Also, the impacts of intensive use of pesticides on all forms of life are observed: there are more than 600 million liters of poison annually, concentrating $73.5 \%$ of the total pesticides consumed in the country in 2018 , which, regarding human health, results in rates of exogenous poisoning and childhood cancer higher than the national averages. The Cerrado biome is characterized as a sacrificial zone of the Brazilian development model where nature, and populations, are plundered to guarantee the accumulation of few in an Ecocide process that is a modern-colonial racist product in this territory.

Keywords: Cerrados (Brazilian Savanna); agribusiness; traditional communities; water spoliation; pesticides poisoning.

\section{Introdução}

Chegou ao limite do suportável o rebaixamento das águas do Rio Arrojado, em Correntina-BA, sem as quais seus ribeirinhos não existem. Apelar às autoridades governamentais de nada adiantou. Dai que, com plena consciência de um Direito Humano fundamental e capacidade de agir por ele, cerca de um mil destes ribeirinhos, em 02 de novembro de 2017, dia de Finados, quebraram e incendiaram as instalações de irrigação agrícola da empresa que lhes sugava o sangue, quer dizer, as águas. Nove dias depois, uma multidão de 12 mil pessoas saiu às ruas da cidade de cerca de 12.600 habitantes (Censo 2010) em apoio àquela ação: "Ninguém vai morrer de sede às margens do Arrojado”. (Ruben Siqueira, pela Comissão Pastoral da Terra/Bahia e Coordenação Nacional da CPT). 
O conflito em Correntina, município situado no Oeste da Bahia, expõe algumas das consequências da expansão do agronegócio no Brasil, especialmente sobre os Cerrados. Esse conflito se constitui em um caso emblemático, como o principal no Brasil relacionado às águas, e remete ao desmatamento do Cerrado, que provoca a redução de vazão e mesmo morte de rios.

Formado há cerca de 65 milhões de anos, os Cerrados ${ }^{1}$ constituem o mais antigo e o segundo maior bioma brasileiro, dominando $36 \%$ do território nacional, sendo 192,8 milhões de hectares de Cerrado Contínuo e 114,4 milhões de hectares para as áreas de transição (Mazzeto Silva, 2009). Essas áreas se encontram nos estados de Goiás, Mato Grosso, Mato Grosso do Sul, Tocantins, Maranhão, Bahia, Piauí, Minas Gerais, São Paulo e Paraná, além do Distrito Federal. Por seu tamanho e complexidade natural, interage com a Amazônia, o Pantanal, a Caatinga e com a Mata Atlântica, constituindo ecótonos de grande complexidade e diversidade vegetal e animal (Barbosa, 2008). Abriga diversas fitofisionomias como os Campos, o Cerradão, Matas, Matas Ciliares, Veredas e Ambientes Alagadiços e o Cerrado propriamente dito. Nele vivem 11.627 espécies vegetais, 250 espécies de mamíferos, 837 espécies de aves, 1.200 espécies de peixes e 150 espécies de anfíbios (MMA, 2009).

O relevo dos Cerrados, geralmente em chapadas e baixões, e sua diversificada vegetação nativa tem relação intrínseca com sua riqueza em águas e com a dinâmica de seu ciclo hidrológico, que conta com três grandes aquíferos, importantes tanto para outros biomas do Brasil como para outros países da
América do Sul: o Guarani, o Bambuí e o Urucuia. Como nos ensina Altair Sales Barbosa: os aquíferos são responsáveis pelas nascentes que dão origem à maioria dos rios do Cerrado. Sua existência está na dependência das águas precipitadas e de suas captações principalmente pelas vegetações de raízes profundas e de sistemas radiculares complexos (Barbosa, 2008).

Essas águas transbordam de seu berço nos Cerrados para perenizar rios da margem direita da bacia hidrográfica amazônica (Araguaia/Tocantins, Xingu, Madeira e Tapajós) e para as bacias do São Francisco, do Paraná e do Prata, do Parnaíba, do Jequitinhonha e do rio Doce. Aos Cerrados estão relacionadas as maiores e preciosas áreas continentais alagadas do Planeta, o Pantanal e o Araguaia.

A descoberta arqueológica de esqueleto de homo sapiens sapiens em Goiás confirma que povos originários vivem nos Cerrados há pelo menos 13 mil anos (Barbosa, 2008), construindo conhecimentos e saberes em estreita relação com os diferentes subsistemas do bioma para sustentar sua reprodução social, como enfatiza Porto-Gonçalves (2019, p. 40-41):

[...] ninguém vive em uma região, seja ela qual for, se não souber caçar, coletar, pescar e/ou eventualmente agricultar, ou seja, se não for capaz de garantir seu alimento e, assim, de se reproduzir de um modo próprio; ninguém vive numa região se não souber curar-se, ou seja, se não for capaz de desenvolver/ inventar uma medicina própria; ninguém vive em uma região se não souber se proteger das intempéries, ou seja, inventar uma arquitetura própria. [...] dito de outro modo, ninguém vive sem conhecimento, sem

\footnotetext{
${ }^{1}$ Adotamos neste artigo a denominação Cerrados, no plural, para nos referir ao Cerrado Contínuo e suas áreas de transição, como recomendam diversos estudiosos do bioma.
} 
saber (alimentar-se, curar-se e habitar). O saber está inscrito na vida, no fazer.

Como herdeiros culturais desses primeiros habitantes, os Cerrados são hoje habitados por uma ampla diversidade de povos e comunidades tradicionais que "representam a sociodiversidade do bioma e ao mesmo tempo são os guardiões do patrimônio ecológico e cultural da região" (ActionAid, RSJDH, 2017, p. 24). São mais de 80 etnias indígenas, reunindo 44.118 pessoas, distribuídas principalmente em terras do Maranhão, Tocantins, Goiás, Mato Grosso e Mato Grosso do Sul,

[...] dos grupos linguísticos Jê e Macro-Jê. No primeiro, encontramos os Timbira (que incluem os indígenas Canela, Krinkati, Pukobyé, Krenjé, Gavião, Krahô), os Kayapó (que incluem os Kubenkranken, Kubenkrañoti, Mekrañoti, Kokraimoro, Gorotire, Xikrin, Txukahamãe), os Xerente, Karajá, Xavante, Xakriabá, Apinayé (hoje tido como do grupo Timbira), Suyá, Kreen-Akarôre, Kaingang e Xokleng. O tronco linguístico maior (Macro-Jê) incluiria ainda os indígenas Pataxó, Bororo, Maxakali, Botocudo, Kamakã, Kariri, Puri, Ofaié, Jeikó, Rikbatsá, Guató e Fulniô, além dos Guarani Kaiowá (Silva, 2009, p. 51).

Como povos e comunidades tradicionais, habitam também os Cerrados os quilombolas, descendentes dos povos pretos sequestrados em África e trazidos ao Brasil para serem escravizados nas sesmarias. Submetidos a condições de vida e trabalho compatíveis com a condição de não humanos que a Modernidade inventou para eles, a fim de justificar o projeto colonial, muitos fugiam das senzalas para tentar constituir comunidades em que pudessem reconstruir sua identidade e cultura - os quilombos. A Lei de Terras, de 1850, já antecipava barreiras para que, com a abolição da escravatura, eles não pudessem ter acesso a terra e fossem levados a ocupar terras devolutas entre os latifúndios em expansão.

A despeito do imaginário de "vazio demográfico" construído e difundido em torno dos Cerrados, vivem ainda em estreita relação de interdependência com o bioma vários grupos e comunidades tradicionais que compõem o campesinato na região:

[...] os geraizeiros (norte de Minas Gerais), os geraizenses (Gerais de Balsas/MA), retireiros (áreas alagadas do Araguaia/MT); beiradeiros, barranqueiros e vazanteiros das beiras e das ilhas do São Francisco (MG); quebradeiras de coco (Zona dos Cocais/MA, PI e TO), pantaneiros (MT e MS), camponeses dos vãos (sul do Maranhão) e outras denominações mais gerais, como varjeiros e ribeirinhos (ao longo dos rios São Francisco, Grande e Paraná), caipiras (Triângulo Mineiro e São Paulo) e sertanejos (norte de Minas, Bahia, Maranhão e Piauí), bem como as comunidades de fundo e fecho de pasto do oeste da Bahia (Silva, 2009 apud ActionAid; RSJDH, 2017, p. 26).

Os ricos e diversificados modos de vida desses povos incluem, em geral, viver em terras devolutas nos chamados baixões, onde chega a água das nascentes nas chapadas, possibilitando a pesca e o cultivo de suas roças de mandioca, arroz, milho, feijão, além da criação de galinhas e porcos. As chapadas são utilizadas como terras comuns para a criação de gado, a caça e a extração de frutos e ervas medicinais. Ou seja, a relação entre as terras comuns da chapada e a posse nos baixões é o que permite a reprodução dos modos de vida desses camponeses posseiros (Alves, 2006).

É este o rico território que o povo de Correntina (e muitos outros) defende(m). 
Atualmente, os Cerrados brasileiros, enquanto espaço produtivo, têm sido aceleradamente tensionados pela expansão do agronegócio ${ }^{2}$, constituindo-se na maior região brasileira produtora de grãos. O modelo produtivo do agronegócio, baseado em extensas áreas de monocultivos, implanta-se a partir do desmatamento, destruindo a biodiversidade e comprometendo o ciclo hidrológico; demanda enormes volumes de água, restringindo seus usos pelas comunidades locais; e ainda, entre outras consequências socioecológicas, utiliza intensivamente fertilizantes químicos e agrotóxicos - 602.303.236 de litros de agrotóxicos no ano de 2018, nos cultivos de soja, cana-de-açúcar, milho e algodão -, os quais têm implicações na contaminação do ar, do solo e das águas e, muito especialmente, no adoecimento de trabalhadores/as e moradores/as (Pignati et al., 2017; IBGE, 2020).

Pretendemos neste artigo defender que está em curso um processo de Ecocídio nos Cerrados brasileiros nas últimas décadas. De acordo com o Estatuto do Tribunal Permanente dos Povos (TPP) ${ }^{3}$, baseado na Declaração Universal dos Direitos dos Povos aprovada em Argel em 4 de julho de 1976,

[...] ecocídio é entendido como o sério dano, destruição ou perda de um ou mais ecossistemas, em um determinado território, seja por causas humanas ou por outras causas, cujo impacto causa uma diminuição severa nos benefícios ambientais dos quais os habitantes desse território desfrutavam.
No intuito de contribuir para qualificar o Ecocídio dos Cerrados, vamos caracterizar especificamente duas das (muitas) implicações socioecológicas relacionadas à expansão do agronegócio sobre o bioma: a espoliação das águas, com aprofundamento nos conflitos em curso no oeste da Bahia e na bacia dos rios Formoso e Javaés em Tocantins; e alguns impactos do uso intensivo de agrotóxicos sobre a saúde dos povos dos Cerrados, como as intoxicações agudas, as más-formações congênitas e os cânceres infanto-juvenis.

\section{O "desenvolvimento" nos Cerrados e as consequências socioecológicas do agronegócio}

Desde o século XVII, os Cerrados e seus povos sofrem e enfrentam a violência do projeto colonial, inaugurada ali pelos bandeirantes em busca de pedras e metais e de escravizados/as em fuga. A colonialidade do poder percorre os séculos e se atualiza na ordem econômica e política do desenvolvimento/modernidade.

Subordinado aos agentes econômicos, o Estado participa ativamente na constituição das condições necessárias à implantação e expansão desse modelo. Já no contexto da ditadura empresarial-militar (1964-1985), em resposta aos crescentes conflitos agrários e à necessidade de aumentar a produtividade do setor agrícola, o Estado desenvolve um conjunto de políticas que vão

\footnotetext{
${ }^{2}$ Neste artigo vamos nos referir ao termo agronegócio a partir do conceito proposto por Guilherme Delgado, que o define como um "pacto de economia política entre cadeias agroindustriais, grande propriedade fundiária e Estado, que impõe cada vez mais uma estratégia privada e estatal de perseguição da renda fundiária como diretriz principal de acumulação do capital para o conjunto da economia" (Delgado, 2012, p. 111).

${ }^{3} \mathrm{O}$ Estatuto atualizado do Tribunal Permanente dos Povos está disponível em: < http://permanentpeoplestribunal.org/estatuto/?lang=es>, sendo a definição de ecocídio trazida no artigo 5 do Estatuto. Acesso em: jan. 2021.
} 
viabilizando a expansão das fronteiras agrícolas sobre os Cerrados, como a implantação de rodovias interligadas nas regiões Norte e Nordeste (Programa de Integração Nacional); do Prodecer (Programa Nipo-Brasileiro de Desenvolvimento do Cerrado), voltado para o Centro-Oeste em sua primeira etapa, para o Oeste Baiano na segunda e atualmente pressionando a expansão da produção de commodities nas bordas da Amazônia; a constituição dos Complexos Agroindustriais (CAI) como estratégia de modernização agrícola, com a participação da Empresa Brasileira de Pesquisa em Agropecuária (Embrapa) na adaptação de cultivares de soja para a exportação; e ainda, entre outros, os mecanismos para facilitar o acesso de fazendeiros e empresários a recursos subsidiados de bancos públicos. Também os governos estaduais tomam iniciativas, como no sul do Piauí, para colocar no mercado um amplo estoque de terras - cerca de 2 milhões de hectares nos anos 1970 (Greenpeace, 2018).

Nas últimas décadas, também os governos considerados como "populares" na América Latina se dobraram sob o que Gudynas (2009) denominou neoextrativismo progressista, ao alimentarem o modelo de desenvolvimento baseado na produção de commodities agrícolas e minerais para o mercado mundializado e na externalização de seus impactos sociais e ambientais. O agronegócio no Brasil é sistematicamente elevado à condição de um dos pilares fundamentais da economia, expandindo as fronteiras agrícolas sobre os territórios de vida dos povos e comunidades tradicionais, o que David Harvey (2005) qualifica como acumulação por espoliação. Isso significa um processo violento de apropriação e expropriação de bens naturais, terras e territórios, criando padrões de conflitos que podem ser vistos em despejos sistemáticos, cessão irregular de terras, cercamento de acesso a terras de uso coletivo e comum - como são os chapadões dos Cerrados, captação e exploração em escala industrial das águas dos rios e de águas subterrâneas, desmatamento com supressão de vegetação nativa (até o uso do chamado "correntão"), assassinatos das populações no campo. Conformam-se assim os conflitos ambientais, entendidos como:

[...] aqueles ligados ao acesso, à conservação e ao controle dos recursos naturais, que supõem, por parte dos atores confrontados, interesses e valores divergentes em torno dos mesmos, em um contexto de assimetria de poder. As linguagens de valoração divergentes em relação aos recursos naturais se referem ao território (compartilhado ou a intervir) e, de maneira mais geral, ao meio ambiente, em relação à necessidade de sua preservação ou proteção. Enfim, tais conflitos expressam diferentes concepções sobre a Natureza e, em última instância, manifestam uma disputa sobre o que se entende por "desenvolvimento" (Svampa, 2016, p. 143).

Tais conflitos se estruturam sobre o racismo, na medida em que os valores, saberes e modos de vida dos povos e comunidades tradicionais são absolutamente desvalorizados e desqualificados pelos agentes hegemônicos, considerando-os "atrasados" e "improdutivos". Com base numa "visão universal da história associada à ideia de progresso, a partir da qual se constrói a classificação e hierarquização de todos os povos, continentes e experiências históricas" (Lander, 2005, p. 13), nega-se a esses povos a possibilidade de afirmar e realizar modos outros de existir. E ainda, tais conflitos impõem desigualdades/injustiças ambientais, já que os danos recaem sobre os grupos sociais vulnerabilizados, numa distribuição desigual dos benefícios e male- 
fícios do desenvolvimento (Coletivo Brasileiro de Pesquisadores da Desigualdade Ambiental, 2013). Ademais, o fortalecimento político do agronegócio trouxe impactos políticos através da bancada ruralista - uma das maiores e mais influentes no Congresso Nacional, incidindo sistematicamente na flexibilização dos marcos regulatórios de ordem ambiental, fundiária, econômica, de ordenamento territorial, trabalhista, entre outros, com repercussões sobre o mercado de terras, unidades de conservação ambiental, terras tradicionalmente ocupadas e de uso comum, assentamentos rurais.

Segundo Frederico (2013), os principais beneficiários da expansão do agronegócio são as empresas transnacionais ou tradings, que controlam a logística, a comercialização e parte substancial do financiamento, além dos especuladores financeiros que investem no mercado de futuro de commodities agrícolas. É o que Oliveira (2012) chamou de um crescente movimento de mundialização da agricultura brasileira que se traduziu na expansão do controle das transnacionais do agronegócio sobre a agricultura nacional - seja pela determinação do padrão tecnológico, seja pela compra/transformação da produção agropecuária, seja pela crescente aquisição de terras por fazendeiros, empresas e grupos estrangeiros. Contudo, o significado desse movimento, com suas três características básicas - a produção de commodities; as Bolsas de Mercadorias e de Futuro, e os monopólios mundiais -, é traduzido no aumento do controle territorial dessas transnacionais, exercendo, em escalas regionais e locais, o monopólio fundiário do território e expulsão dos povos e comunidades tradicionais via grilagem de terra.

No Brasil, em 2018, os cultivos de soja, milho, cana-de-açúcar e algodão ocuparam um total de 62.542.022 hectares de área plantada, ao que se soma uma área de pastagem de 169,6 milhões de hectares e um rebanho de 213,5 milhões de cabeças de gado. Essa produção está fortemente concentrada nos Cerrados, que teve área plantada de 46.889 .008 hectares para essas commodities no mesmo ano - o que representa $75 \%$ do total plantado no país (Figura 1). Além disso, as pastagens ocupam 63.847 .127 hectares dos Cerrados, representando 37,6\% de toda a área de pastagem do país, nos quais encontram-se 117.199 .138 cabeças de gado $(54,9 \%$ de todo re-

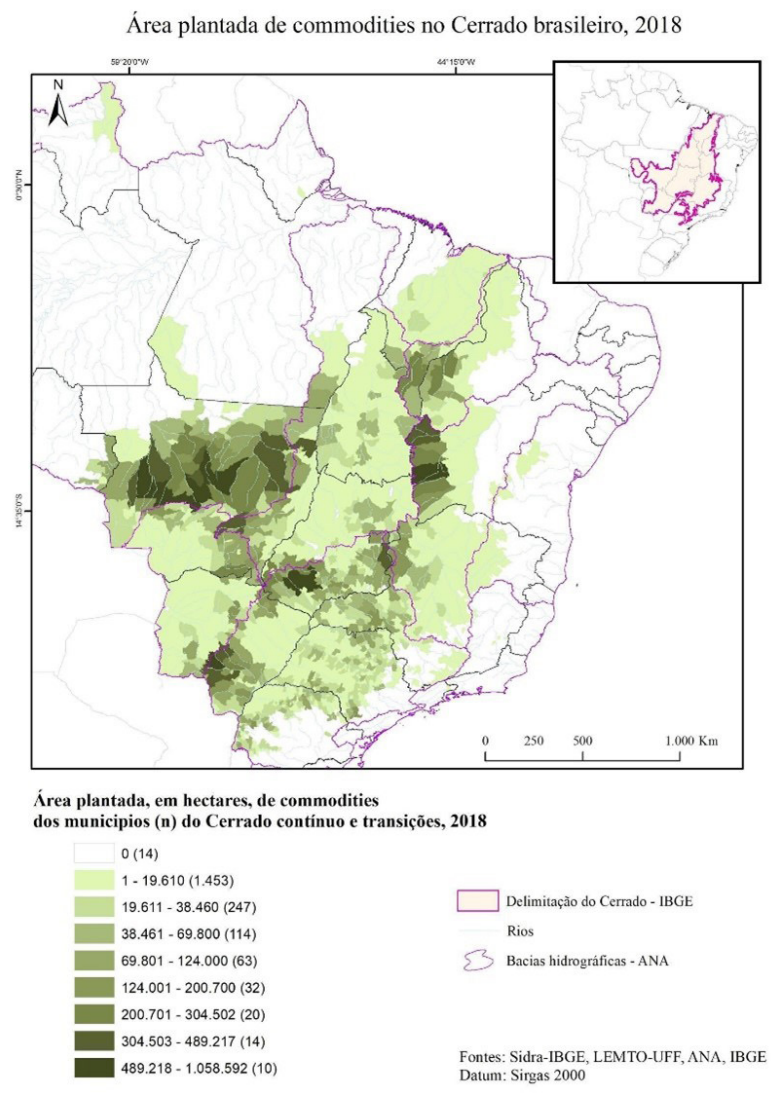

FIGURA 1 - Área plantada, em hectares, de commodities (soja, milho, cana-de-açúcar e algodão) nos Cerrados e bacias hidrográficas brasileiras, 2018 
banho bovino no Brasil), com severas implicações sobre as emissões de gases de efeito estufa (IBGE, 2020; LAPIG, 2020).

Entre os cultivos de commodities selecionados, a produção de soja nos Cerrados responde por 24.627.450 hectares de área plantada $(52,5 \%)$, seguida do milho com 12.435 .639 hectares $(26,5 \%)$, da cana-de-açúcar com 8.682.674 hectares $(18,5 \%)$ e do algodão com 1.143.245 hectares (2,4\%) (IBGE, 2020).

Boa parte dessa dinâmica mais recente de expansão se deve à implementação do Matopiba nos estados do Maranhão, Tocantins, Piauí e Bahia, no governo Dilma Rousseff, quando a então ministra da agricultura, Kátia Abreu, aprova o decreto $\mathrm{n}^{\circ}$ 8.447 de maio de 2015 que dispõe sobre o Plano de Desenvolvimento Agropecuário da região, deslocando um montante significativo de recursos via obras do PAC do governo federal, sobretudo no que tange às obras de irrigação para o agronegócio. Apenas no Tocantins os valores, em cooperação com outros ministérios e o Banco Interamericano de Desenvolvimento (BID), são da ordem de 650 milhões de reais para o ano de 2016, sendo 450 milhões de reais para a revitalização do projeto de irrigação Rio Formoso. Esse decreto, junto aos estudos projetados pela Embrapa, delimitam uma área de 73 milhões de hectares. Além de terras agricultáveis, conta com aporte energético estratégico a partir de águas vertentes para as bacias dos rios Paraná, São Francisco, Tocantins e Parnaíba, e ainda localiza os três grandes aquíferos - Guarani, Bambuí e Urucuia. O Matopiba é a região do Brasil com maior crescimento percentual da área plantada de soja, milho e algodão, as quais, somadas, cresceram $32 \%$ na safra de 2000/01 e 193\% na safra de 2014/15 (Frederico \& Almeida, 2019). Concomitantemente, a Região do Matopiba teve perda de cobertura da vegetação natural de 94 mil quilômetros quadrados no período entre 1985 e 2017.

O bioma como um todo apresenta um dos maiores índices de desmatamento do país - 52\%, sendo que apenas entre 2019/2020 os Cerrados perderam 29 milhões de hectares de vegetação nativa, enquanto foram implantados 28 milhões de hectares destinados a atividades agropecuárias (MapBiomas, 2019/2020; Santos \& Glass, 2018). O desmatamento tem outro efeito ambiental danoso que é a erosão do solo e o carreamento de sedimentos para os cursos d'água. Na bacia do rio São Francisco, estudo do Exército Americano e da Codevasf(CBHSF, 2020) estimou que o rio São Francisco recebe por ano cerca de 23 milhões de toneladas de sedimentos, assoreando sua calha principal e a de seus afluentes. Segundo esse mesmo estudo, tal processo decorre do desmatamento feito nos planaltos dos Cerrados pelas áreas de produção, contribuindo para a redução de vazão do rio, formação de ilhas e depósitos de areia, com restrições à navegação e acelerando o processo de degradação do rio.

Segundo Barbosa (2014), as entropias decorrentes do desmatamento produzem processos imprevisíveis e irreversíveis. A retirada da cobertura vegetal, removendo árvores de raízes profundas e sistemas radiculares complexos dos Cerrados, além da supressão de suas gramíneas, restringe a infiltração da água no solo, reduzindo a recarga dos aquíferos, que se dá sobretudo nas vastas áreas das chapadas. Um terço da massa corpórea da vegetação dos Cerrados está sobre a superfície e dois terços no subsolo, o que é essencial para a infiltração da água no solo, decorrente dos sistemas radiculares. Com o desmatamento, ocorre a compactação e o aumento do escoamento superficial. 
A espoliação provocada por esse modelo produtivo, além de baseada em forte expansão territorial sobre áreas de vegetação nativa, sustenta-se em uma superexploração e consumo de água, através de sistemas de irrigação que comprometem o ciclo hidrológico. Segundo a Agência Nacional de Águas (ANA), em relatório publicado em 2019, a agricultura irrigada consome $66,1 \%$ das águas; $11,6 \%$ se destinam ao consumo animal; $9,1 \%$ à indústria e também 9,1\% ao abastecimento urbano; $2,5 \%$ ao abastecimento rural; $0,9 \%$ à mineração e $0,3 \%$ para termelétricas. Ademais, a agricultura irrigada é responsável pela retirada de 969 mil litros de água por segundo das fontes de água superficiais e subterrâneas, o que significa 83 bilhões de litros de água por dia (ANA, 2019a) - enquanto que a média de consumo diário de cada brasileiro é de 150 litros.

O Brasil está entre os dez países com a maior área equipada para irrigação do mundo, somando 4 milhões de hectares em 2016 (ANA, 2017) e atingindo 7,3 milhões de hectares em 2019 (ANA, 2019b). Até o ano de 2017 o país possuía 23.181 pontos-pivôs com 1.476.101 hectares equipados para irrigação (Figura 2), aos quais se somaram 94 mil hectares ao ano no período 2012-2018, com tendência a intensificar tal processo até 2030 (ANA, 2019a). Tal projeção sinaliza um aumento da retirada do volume de água nessa atividade, que passaria dos 969 mil litros por segundo para 1,338 milhão de litros por segundo em 2030, um aumento estimado em 38\% (ANA, 2019b).

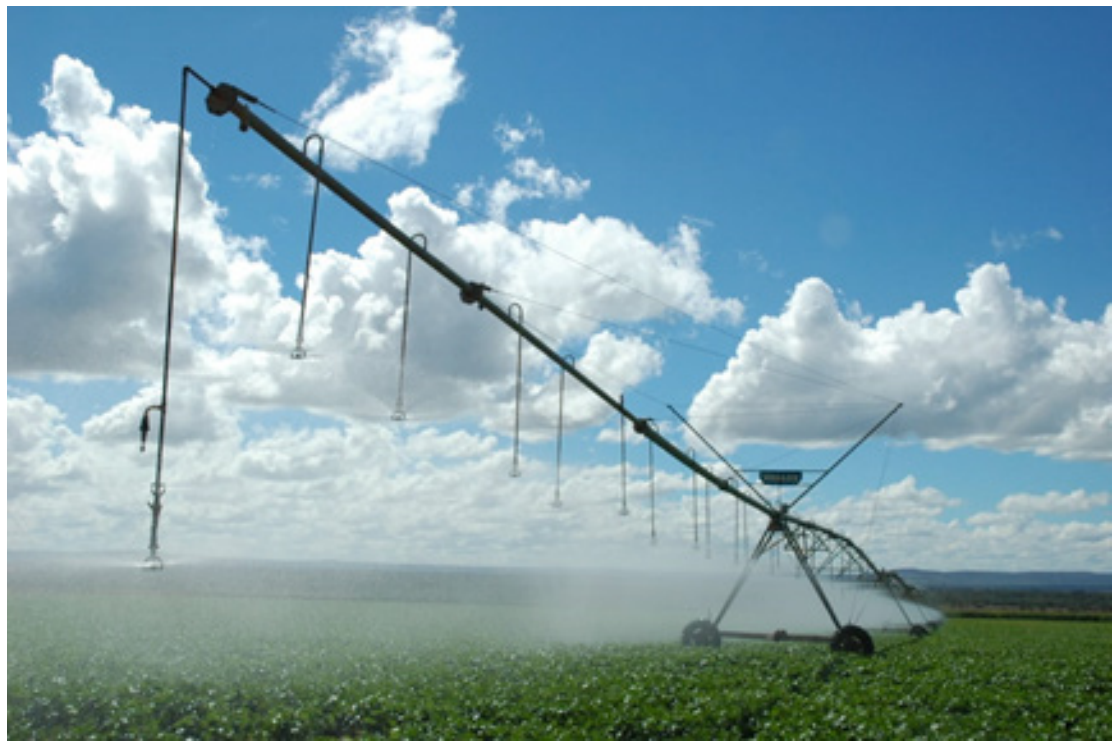

FIGURA 2 - Pivô central utilizado para irrigação de monocultivos.

FONTE: Foto de João Zinclar, doada à Articulação Popular São Francisco Vivo e gentilmente cedida por esta à presente publicação. 
Essa expansão das áreas equipadas está, em sua maioria, localizada nos Cerrados, cujos estados concentram $91,8 \%$ da área equipada por pivôs (ANA, 2019b). Na Região Hidrográfica do São Francisco, observa-se uma concentração dessas áreas no Oeste da Bahia, especialmente nas bacias dos rios Grande, Correntes, Carinhanha e Paracatu, o qual deságua no São Francisco e tem o Entre-Ribeiros e o Preto como afluentes ${ }^{4}$.

A acelerada expansão do agronegócio sobre os Cerrados, com desmatamento suprimindo a mata nativa, associado à captação intensiva das águas dos aquíferos e dos rios, repercute sobre o volume de água contido nos aquíferos. Além de provocar a diminuição da vazão dos rios - pois o que mantém a perenização dos rios são os aquíferos que os alimentam -, pode provocar a interrupção de trechos dos rios ou até mesmo a morte de afluentes dos rios principais, o que pode ter implicações no sistema de abastecimento dos principais rios do país e no colapso nas regiões hidrográficas do subcontinente sul-americano.

É esse o contexto que nos permite compreender a elevação do número de conflitos por água no Brasil. Entre 2015 e 2019, o Centro de Documentação da Comissão Pastoral da Terra, registrou média anual de 254 conflitos por água no país, sendo o mais emblemático de todos, o de Correntina, no Oeste da Bahia. Para o ano de 2019, esse número chegou a 489, com o envolvimento de 279.172 pessoas - o que representa um crescimento da ordem de $77 \%$ em relação a 2018 (CPT, 2020, p. 139), e reflete a injustiça hídrica que atinge os povos e comunidades tradicionais. Como enuncia o lema da Campanha Nacional em Defesa do Cerrado: sem Cerrado, sem água, sem vida ${ }^{5}$.

A essa expansão do agronegócio associa-se também, no modelo preconizado pela chamada modernização agrícola, a intensificação do uso de agrotóxicos, no que o Brasil tem ocupado as primeiras posições entre os maiores consumidores do mundo, na última década. No ano de 2018, foram comercializadas 549.280 toneladas de agrotóxicos, utilizados em um total de 78,5 milhões de hectares de área plantada ou destinada à colheita de cultivos diversos no país - isso sem incluir os produtos contrabandeados (comercialização ilegal/ produtos não aprovados no país), que se estima que correspondam a cerca de $20 \%$ das vendas totais. A maior parte desses venenos é utilizada nos cultivos de algodão, cana-de-açúcar, milho e soja, os quais consumiram 838.478.552 de litros de agrotóxicos no ano de 2018 (Pignati et al., 2017; Fiocruz, 2018).

Nos Cerrados, o cultivo que apresenta o maior consumo de agrotóxicos é a soja, que totalizou 435.905.865 de litros $(72,4 \%)$ em produto formulado, seguido dos cultivos de milho com 92.023.729 de litros (15,3\%), cana-de-açúcar com 41.676 .835 de litros $(6,9 \%)$ e algodão com 32.696.807 de litros (5,4\%). Juntos eles somaram 602.303.236 litros de venenos aplicados sobre os municípios dos Cerrados, concentrando $73,5 \%$ do total de agrotóxicos consumidos no Brasil em 2018, o que caracteriza uma intensa zona de sacrifício (Figura 3).

\footnotetext{
${ }^{4}$ Portal do SNIRH - Sistema Nacional de Informação de Recursos Hídricos: Usos da Água. Disponível em: <www.snirh.gov.br>. Acesso em: jul. 2020.
}

${ }^{5}$ Mais informações disponíveis em: <https://semcerrado.org.br>. Acesso em: jul. 2020. 


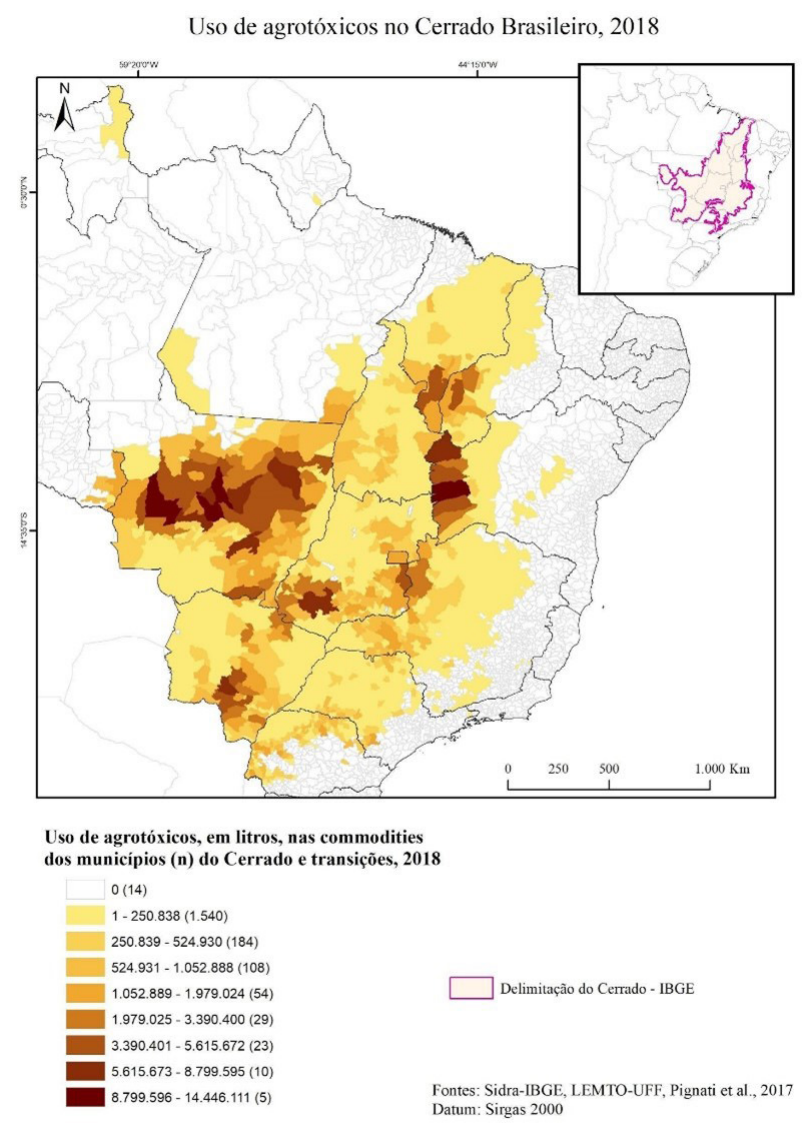

FIGURA 3 - Consumo de agrotóxicos, em litros, em commodities agrícolas (soja, milho, cana-de-açúcar e algodão) nos Cerrados do Brasil, 2018.

Analisar essas consequências do projeto moderno-colonial sobre os Cerrados, expresso nas últimas décadas num modelo de desenvolvimento promovido pelo Estado, afinado aos interesses das oligarquias latifundiárias e às corporações transnacionais que espoliam terras, águas e povos do bioma para expandir, através do agronegócio, o cultivo de commodities agropecuárias, permite compreender a conflitividade presente no bioma, em resposta às desigualdades e injustiças impostas a seus povos, que veem profundamente ameaçadas, quando não inviabilizadas, suas formas tradicionais de organizar a vida. Tais consequências transbordam os Cerrados, comprometendo outras regiões alimentadas por suas águas, no âmbito do continente sul-americano, ao tempo em que representam inestimáveis perdas de saberes, biodiversidade e perspectivas de futuro.

\section{A espoliação das águas incide sobre os territórios e modos de vida de comunidades tradicionais nos Cerrados}

\begin{abstract}
“(...) Nós viajamos mais ou menos uns quinze dias beirando o rio Tocantins (...) naquele tempo tinha um gerais monstro que não tinha ninguém, você chegava e ia escolhendo aonde achava bonito para morar ali e ficava. Não tinha morador e nada. A terra ninguém sabia se tinha dono... Era geraiszão mesmo". (Joaquim, oficina de mapas, Projeto Nova Cartografia Social da Amazônia, Manaus, 2009).
\end{abstract}

Os modos de vida de populações tradicionais se caracterizam pelos vínculos comunitários e com os ecossistemas onde vivem, por meio de produção e trabalho na agricultura, caça, pesca, coleta e criatório, que afirmam valores, costumes e crenças. Esses elementos configuram as diversas comunidades tradicionais, em apoio e suporte comunal para a reprodução social, conformando modos de vida distintos. Segundo Brandão (2010), nos modos de vida tradicionais, há uma autonomia relativa, na qual, em geral, a posse da terra é precária e, segundo esse autor, há a presença do outro, que pode ser o fazendeiro, o grileiro, o fundo de investimento ou o Estado. Nesse modo de vida, qualquer ação de poder externo sobre os territórios de vida deflagra 
'processos de vulnerabilização ${ }^{6}$, que produzem sofrimentos e deflagram conflitos socioambientais.

No Oeste da Bahia viveram dezenas de povos indígenas. Atualmente há três povos em processo de reemergência, distantes de seus territórios originários - os Kiriri (Barreiras), Atikun (Santa Rita de Cássia) e Xacriabá (Cocos) -, que buscam reconectar os vínculos ancestrais que lhes conformam uma identidade. As comunidades quilombolas estão sobretudo na bacia do rio Grande, a cerca de 300 anos, constituídas por grupos de pessoas escravizadas e que saíram dos currais ao longo do rio São Francisco e de Pernambuco, bem como do Arraial de Canudos. Os camponeses constituem diversas e ricas identidades relacionadas a suas origens, aos ecossistemas onde vivem e às atividades produtivas que exercem. Nos campos largos dos gerais ou nos baixões, podem ser geraizeiros, fundo e fecho de pasto, quilombolas, extrativistas, ribeirinhos, ou ainda agricultores familiares.

A vida e a reprodução das comunidades tradicionais no Oeste da Bahia se complementa entre as chapadas ou os gerais, e os vales ou veredas, sendo estas as duas unidades indivisíveis da paisagem, como defende Porto-Gonçalves (2019). Com a chegada das grandes empresas do agronegócio a partir dos anos 1970, é iniciada a grilagem das terras nos gerais e os modos de vida vêm sendo ameaçados. Rupturas no metabolismo sociedade-natureza passam a se intensificar, produzindo processos de vulnerabilização nas comunidades tradicionais, decorrentes da degradação ambiental imposta pelo grande capital e pelo Estado. Mais recentemente, a grilagem de terras passa a ocorrer também nas veredas ou baixões, para se constituírem em reservas legais, necessárias para que o agronegócio atenda às exigências legais de manter áreas de preservação.

Merecem destaque as sabedorias e práticas ancestrais que orientam os diversificados usos comunais das águas, envolvendo não só sua gestão e manejo para o consumo domiciliar, os cultivos agrícolas, as atividades pecuárias e de pesca, mas também as práticas sociais de natureza lúdica e ritualística/sagrada. Tais sistemas comunais são comprometidos pelo intenso e conflituoso processo de desmatamento e captura das águas dos rios e dos aquíferos para irrigação dos monocultivos, principalmente nos chapadões que, como vimos, são as áreas mais importantes de recarga dos aquíferos. Daí advém o processo de migração de nascentes, o stress hídrico nas bacias e sub-bacias hidrográficas, a morte parcial de rios principais e desaparecimento de rios de outras ordens da mesma bacia, diminuição das vazões dos rios e aquíferos, entre outros impactos (Figura 4).

Para bem observar esse processo de espoliação das águas pelo agronegócio, o Oeste da Bahia e a bacia do rio Formoso, no Tocantins, são casos emblemáticos, em que a implementação de projetos dos monocultivos, dependentes de uso intensivo das águas, ocorrem desde os anos 1970.

\footnotetext{
${ }^{6} \mathrm{O}$ conceito de vulnerabilização foi adotado no presente artigo a partir de uma compreensão ampliada a respeito das injustiças, assimetrias e violações de direitos engendradas historicamente e cotidianamente a determinadas populações. Os sujeitos que fazem parte dessas comunidades sofrem as consequências de estarem desassistidos por um Estado que não garante o cumprimento de muitos direitos conquistados e ainda atua para facilitar a implementação de grandes empreendimentos que espoliam os territórios e adoecem as pessoas. Por isso, refletir a respeito dos processos de vulnerabilização que atravessam essas comunidades é um passo além de apenas identificar e caracterizar as vulnerabilidades individuais e coletivas (Acselrad, 2013).
} 


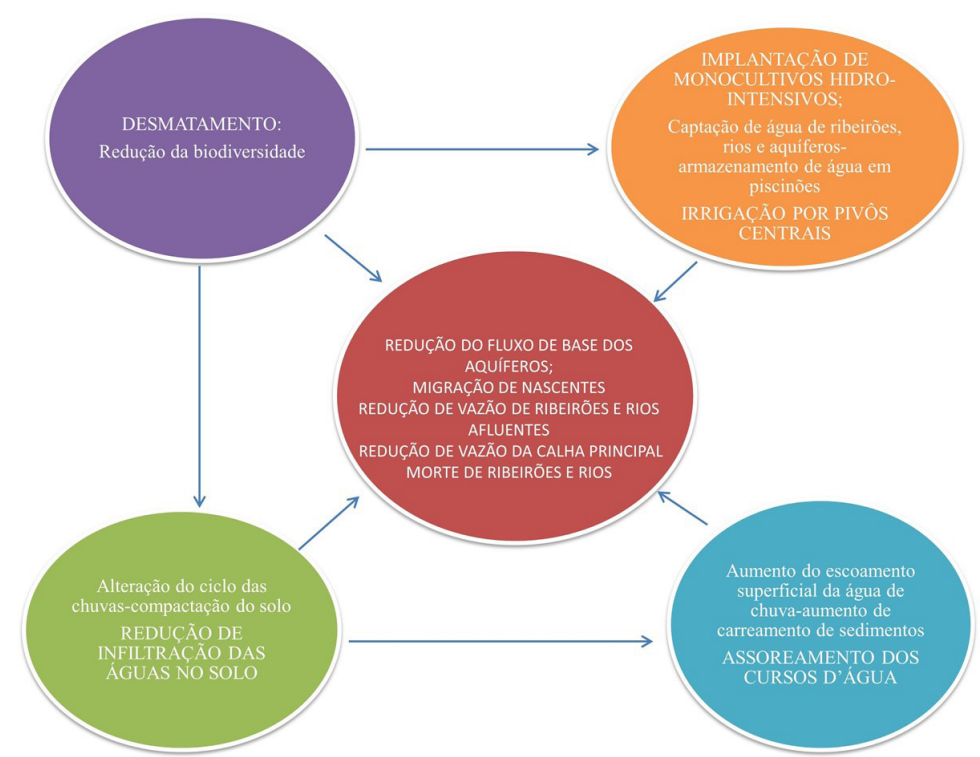

FIGURA 4 - Mudanças no uso da terra e processos de espoliação das águas no Oeste Baiano pelo agronegócio.

FONTE: Elaborada pelos/as autores/as.

No caso do Oeste da Bahia, trata-se de uma região de expansão do monocultivo de soja, baseada na irrigação por pivôs centrais, que usam as águas dos rios e principalmente dos aquíferos; já no caso do Tocantins, predomina um projeto de irrigação para monocultivo de arroz - o Projeto Rio Formoso, que se serve das dinâmicas de cheias das áreas alagadiças desse importante ecótono dos Cerrados, reconhecido como área úmida de relevância da biodiversidade no mundo. A figura 5, o Mapa de Balanço Hídrico das bacias e sub-bacias, possibilita observar, à esquerda, o rio Formoso (TO), e à direita, o Oeste Baiano (BA), ambos em situação muito crítica, de acordo com os critérios estabelecidos pela Agência Nacional de Águas.

Tal processo intensivo de espoliação das águas está intrinsecamente relacionado à expansão das áreas de cultivo de commodities agrícolas do agronegócio nas regiões destacadas acima. Os da- dos disponíveis da Produção Agrícola Municipal do IBGE indicam que, em 25 anos (1993-2018), o Oeste da Bahia passou de uma área total ocupada com lavouras temporárias de 620.732 hectares para 2.246.821 hectares, representando um incremento de mais de 360\% (IBGE, 2020).

Se, em 1993, as quatro principais commodities agrícolas do agronegócio - soja, algodão, cana-de-açúcar e milho - ocupavam uma área total de 483.810 hectares, o que equivalia a quase $78 \%$ da área total com lavouras temporárias para aquele ano, em 2018, esses monocultivos ocupavam $94,5 \%$ do total da área de lavouras temporárias. Cabe destaque à área plantada de soja no Oeste da Bahia - principal monocultura de expansão do agronegócio sobre os Cerrados -, que passou de 381 mil hectares em 1993 para mais de 1.600 .000 hectares em 2018, equivalente a um aumento de $420 \%$ de área plantada em apenas 25 anos (IBGE, 2020). 


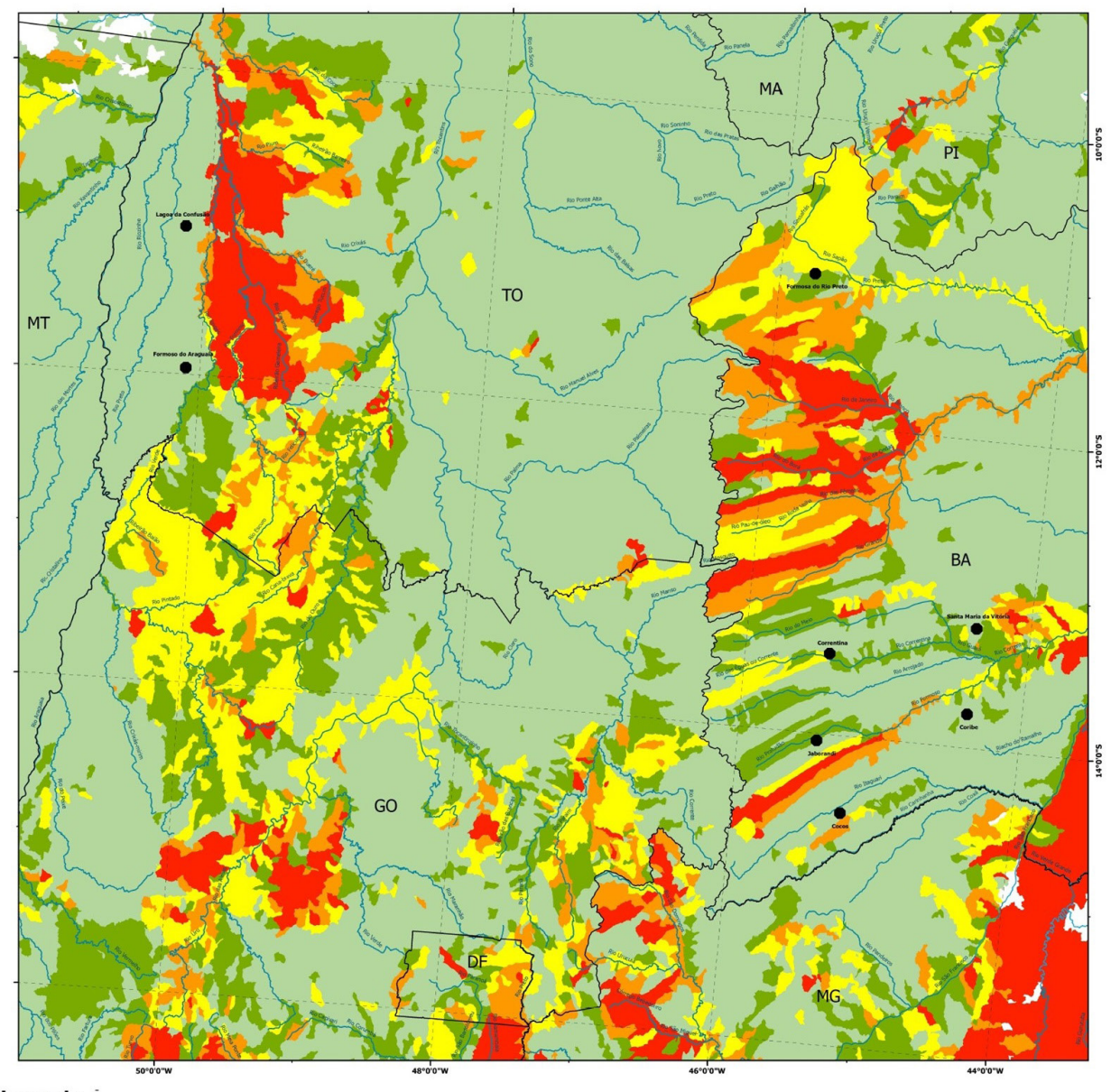

\section{Legenda \\ $\sqrt{3}$ UF \\ - Rios \\ Casos representativos \\ - Municípios}

Balanço hidrico Quantitativo (Por microbacia)

Excelente (<5\%)

Confortável (5\% - 10\%)

Preocupante (10\% - 20\%)

Crítica (20\% - 40\%)

Muito Crítica (>40\%)

o balanço hidrico quantitativo é a razão entre a vazão de retirada para os usos consuntivos $e$ a disponibilidade hidrica. As

são as industriais e de irrigacão (atualizadas até 2014) a do

abastecimento urbano e dessedentaço animal (atualizadas até

2013).

Fonte: Agência Nacional de Águas

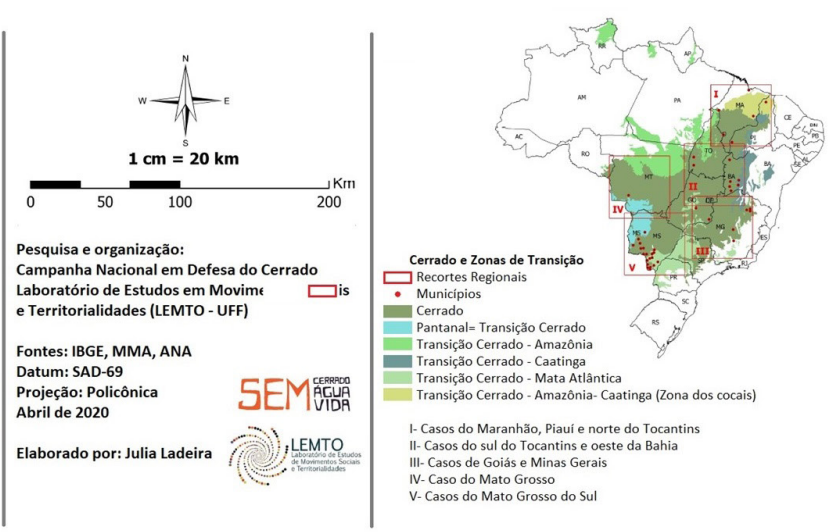

FIGURA 5 - Mapa do balanço hídrico quantitativo da espoliação das águas nos territórios do Oeste da Bahia e do Formoso-Bananal, 2014. 
Já na região da bacia do Rio Formoso, no Tocantins, destacamos que a área ocupada com lavouras temporárias, em 1993, era de 53.578 hectares e, em 25 anos, 2018, chegou a 189.200 hectares, um aumento de mais de $350 \%$ para aquela escala (IBGE, 2020). Essa região tem como especificidade uma forte predominância do cultivo do arroz, dada sobretudo pelo Projeto de Irrigação Rio Formoso, implementado desde 1970. Em 1993 essa cultura ocupava 43.166 hectares, o que correspondia a $80,5 \%$ da área ocupada com lavouras temporárias. Os dados do IBGE mostram que ao longo dos últimos 25 anos (1993-2018) a área plantada de arroz dobrou, com um total de 87.069 hectares, o que correspondia, em 2018, a 46\% do total da área ocupada (IBGE, 2020).

Entretanto, o processo de expansão do agronegócio nessa região vai ocorrer tanto com a permanência da expansão da área do cultivo de arroz como também com um forte acréscimo de área plantada de soja, principal commodity do agronegócio nos Cerrados. Em 1993, as áreas de cultivo de arroz e de soja juntas correspondiam a 80,6\% da área plantada com lavouras temporárias, porém a soja representava $13 \%$ dessa área, o que equivale a menos de 7.000 hectares. Ao longo dos últimos 25 anos, a área plantada de soja passou a ocupar 76.191 hectares, o que corresponde a um aumento de $1.100 \%$, enquanto que a área plantada de arroz diminuiu, relativamente. Em 2018, a diminuição da importância relativa de área plantada de arroz na região deve-se ao avanço da soja, onde a área ocupava $46 \%$ da área plantada, enquanto que a soja saltou de 13\%, em 1993, para 40\% em 2018 (IBGE, 2020). Ademais cabe destacar que as Projeções do Agronegócio Brasil 2016/2017 a 2026/2027 (MAPA, 2017) apontam para a perspectiva de um aumento de área plantada de 9.3 milhões de hectares sobre os Cerrados do país.

A expansão exponencial do agronegócio determina processos de vulnerabilização para os povos e comunidades tradicionais, com perdas materiais e simbólicas. Além dos crimes ambientais e grilagem de terra, o trabalho escravo é outra face do agronegócio. Os 24 municípios do Oeste da Bahia respondem por cerca de um terço do trabalho escravo nesse estado. Segundo o Observatório da Erradicação do Trabalho Escravo e do Tráfico de Pessoas $^{7}$, entre 2003 e 2018, foram resgatadas 4.146 pessoas em trabalho análogo ao de escravo nessa região. Nos 4 municípios do Formoso/Araguaia, no Tocantins, no mesmo período foram 132 pessoas nas mesmas circunstâncias. Regiões expoentes de tecnologia de ponta e do capital financeiro agrário, reproduzindo modelos arcaicos de degradação ambiental, espoliação das águas e a perversidade do trabalho escravo.

\subsection{O caso do Oeste da Bahia}

O contexto da gestão estatal das águas no Oeste Baiano é permissivo ao capital agropecuário, sendo alarmante, por exemplo, o diagnóstico relacionado às vazões outorgadas pelo Estado, sem o controle adequado das vazões consumidas pelo órgão gestor (Inema/BA). Foi o que levou ao conflito de Correntina, relativo à superexploração hídrica pelo Grupo Igarashi, na bacia do rio Arrojado. A

\footnotetext{
${ }^{7}$ Mais informações estão disponíveis em: <https://smartlabbr.org/trabalhoescravo>. Acesso em: nov. 2020.
} 
promotora pública da Bahia desvela esse contexto permissivo (Khoury, 2018, p. 77):

[...] as grandes captações que são outorgadas pelo órgão gestor, sem as atualizações de dados de medições das vazões, sem o acompanhamento dos impactos daquela outorga concedida para o ecossistema e para a preservação ecológica do rio, sem interpretação dos efeitos sinérgicos de outros empreendimentos na mesma bacia, sem análise dos impactos negativos em comunidades vizinhas da região, pode-se concluir que a outorga tem sido um instrumento cartorial, sem uma capacidade de efetivo controle do uso da água.

A bacia do rio Corrente é uma das principais impactadas pelo agronegócio no Oeste Baiano. Levantamento do Núcleo da Diocese de Bom Jesus da Lapa/Arquivo da CPT-Centro-Oeste da Bahia aponta que, nessa bacia, de 45 rios analisados, apenas 05 são perenes, 02 estão mortos (secam na estiagem, sem vegetação na nascente), 02 são semi-perenes (têm vegetação e água, mas estas não chegam ao curso final no período seco) e 36 são secos (secam durante o período de estiagem, mas mantêm vegetação na nascente).

Estudo realizado por Gonçalves et al. (2018) aponta redução do fluxo de base do Sistema Aquífero Urucuia (SAU) para o Rio São Francisco. O ciclo histórico mais intenso de redução nesse fluxo de base do SAU ocorreu a partir de 1980, quando a vazão era de 792 metros cúbicos por segundo, e caiu para 402 metros cúbicos por segundo, em 2015 - uma redução de 49,2\% na alimentação do Rio São Francisco (correspondente a 390 metros cúbicos por segundo) em 35 anos. Segundo os autores, o contexto que determinou a depleção das águas é composto por cinco processos: a alteração no regime de chuvas, a explotação de águas subterrâneas, a captação de águas superficiais, o represamento dos rios, e a irrigação e compactação do solo em áreas de recarga. Silva (2020) relaciona o primeiro processo - a alteração do regime de chuvas, apresentando "tendências de queda das precipitações médias entre $67 \%$ e $88 \%$ " -, com as mudanças de uso e cobertura do solo desencadeadas pelo desmatamento (Silva, 2020, p.106).

Na figura 5, observa-se que o balanço hídrico na região já era preocupante em 2014, devido ao volume consumido, fundamentalmente, pelo agronegócio. As piores vazões ocorrem na parte setentrional dessa região, nos afluentes da margem direita do Rio Preto - sub-bacias do Rio Ribeirão, Riachão, e Rio do Ouro -, em que a situação é crítica (onde o consumo pelo agronegócio era entre $20 \%-40 \%$ da vazão do rio). Nas bacias afluentes do Rio Grande e no entorno de sua calha principal, notadamente na microbacia do Rio de Janeiro, do Rio de Ondas e no alto Rio Grande, as manchas vermelhas denotam que o balanço hídrico é muito crítico, ou seja, o agronegócio consome acima de $40 \%$ da vazão dos rios. No baixo Rio Grande, a situação é crítica. $\mathrm{Na}$ parte meridional do Oeste Baiano, no alto Rio Formoso, afluente do Rio Corrente e no trecho baixo desse rio, a situação é também muito crítica.

A espoliação das águas e sua depleção se potencializam com os "piscinões" construídos no Oeste da Bahia com o objetivo de equacionar soluções para manter a produção quando a vazão dos rios já não é suficiente para alimentar os pivôs centrais. São enormes reservatórios escavados no solo e impermeabilizados, alimentados pela captação subterrânea de água, de forma a armazenar e suprir a vazão diária requerida para a irrigação. Iremar Barbosa, importante liderança da região da 
bacia do rio Corrente, assim descreve esse processo (Cunha, 2017, p. 38):

Está se disseminando uma tecnologia chamada de pivô central à base de piscinões no Oeste da Bahia. Um piscinão feito em Correntina por exemplo, tem a capacidade de 200 milhões de litros de água. Tem uma propriedade lá que tem dez piscinões abertos e o Tribunal de Justiça - TJ da Bahia autorizou esse funcionamento agora... ou seja, é indecente o que tá acontecendo no Oeste da Bahia.

Esses processos de espoliação vulnerabilizam as comunidades tradicionais centenárias, afetando seus modos de vida e coagindo-as a abandonarem seus territórios de vida, como denúncia Jamilton Magalhães, o Carreirinha (Mota \& Motoki, 2020, n.p.), liderança da bacia do rio Corrente:

A partir de [19]70-80, surgiu a necessidade de cercar, porque a grilagem de terra chegou. Aí o pessoal teve que se juntar, em comunidades, em parentesco, compadrio e determinar o seu território. E assim foi feito o fechamento do seu território para defender e lutar para defender o modo de vida... não foi fácil enfrentar esse povo que vem de fora para explorar. Ser de fecho de pasto é ser uma comunidade que tem sua independência.

Orgulhoso da autonomia conquistada anteriormente, Carreirinha afirma que "na nossa comunidade o que entrava mesmo, de fora, era só o sal, que tinha que ser buscado no comércio. No mais, era tudo produzido na comunidade" (Mota \& Motoki, 2020, n.p.). Ou ainda: "esse modo de vida quero que seja respeitado pelos governantes. É nos fechos que tem os territórios preservados, que tem suas matas, seu Cerrado em pé” (Mota \& Motoki, 2020, n.p.).
Esse modo de vida tradicional é negado e se impõe a presença do outro, que pode ser o grileiro, o capanga, o fundo de investimento, os condomínios empresariais e o trabalho escravo, que negam a legitimidade de sua existência e instauram processos de vulnerabilização, como afirma Carreirinha: "[...] com a chegada deste povo do sul do país e até de outros países também, começou a apossar desta terra trazendo documentos forjados, escrituras montadas e com capangas, pistolagem" (Mota \& Motoki, 2020, n.p.).

As comunidades que se localizam nos baixões ou brejos há centenas de anos foram proibidas, por legislação ambiental do Inema/BA, de fazerem suas roças, de produzirem seus próprios alimentos, com suas "múltiplas práticas de apropriação das condições naturais necessárias à reprodução da vida - terra-solo-relevo-subsolo-clima-água-plantas-animais" (Porto-Gonçalves \& Chagas, 2019, p. 41), como vemos no relato de Andreia Neiva, do Movimento dos Atingidos por Barragem (2017 apud Porto-Gonçalves \& Chagas, 2019, p. 33):

\begin{abstract}
Somos vítimas de um processo de desenvolvimento que não nos considera, que não nos respeita. Que os nossos filhos, e os filhos que ainda vamos ter, tenha acesso aos gerais, que possam ir passear e ver as veredas, catar pequi, comer mangaba, comer puçá, que possam ter a vida que nós tivemos, a infância que nós tivemos.
\end{abstract}

A negação da legitimidade da existência do outro, esse outro indesejável ao agronegócio - uma expressão do racismo -, tem provocado conflitos socioambientais no Oeste Baiano desde os anos 1980, mesmo porque os povos e comunidades tradicionais 
têm a força e a determinação de defenderem seus territórios e modos de vida.

O conflito por água em Correntina/BA, relativo à captura das águas pelo agronegócio, teve origem em 1982. Com episódios conflituosos em 2002, e retomado em 2015, com uma grande manifestação de rua, com 6 mil pessoas, e, em 2017, a captura das águas do Rio Arrojado pelo Grupo Higarashi teve repercussão nacional em novembro de 2017 (Porto-Gonçalves \& Chagas, 2019).

No dia 02 de novembro de 2017, ocorreu a destruição de diversos equipamentos em duas fazendas desse Grupo, conduzida por cerca de mil agricultores, esgotados com a parcialidade da ação do Estado e constrangidos pela ameaça de inviabilização de seus cultivos pela falta de acesso à água. Com a alcunha de assassinos, agricultores e moradores realizaram manifestação estimada em 12 mil pessoas, no dia 11 do mesmo mês (Porto-Gonçalves \& Chagas, 2019). Segundo esses autores, a digna raiva é legítima, como atesta Andreia Neiva (Tatemoto, 2017, n.p.):

[...] estão saqueando nossas águas, estão roubando. Pode até ser legal, mas não é legítimo. Nós tivemos várias tentativas de diálogo. Nada foi encaminhado. Chega um momento em que é preciso um ato de rebeldia para ser ouvido.

A relação entre a captura da água pelo agronegócio e os conflitos socioambientais é relevante para a compreensão desses processos em territórios. Estudo realizado por Carvalho (2019) identifica no caso de Correntina que mudanças ocorridas nos cursos de água com drástica redução de vazão, como referem os camponeses, têm relação com mudanças no solo e com as demandas da produção irrigada de soja, algodão e milho. Sua elevada pegada hídrica azul - ou seja, águas superficiais ou subterrâneas agregadas ao produto - permite estimar o "roubo" para além do volume outorgado:

a magnitude do valor da pegada hídrica azul encontrado sugere que o horizonte de consumo de água apontado pela expansão e intensificação da produção agrícola de commodities na bacia do rio Corrente indica um acréscimo de demanda de água próximo ao dobro do valor outorgado atualmente (Carvalho, 2019, p.158).

Outro conflito socioambiental relevante decorre da grilagem de enorme extensão de terra $-43 \mathrm{mil}$ hectares, pelo Agronegócio Condomínio Cachoeira do Estrondo, desde 1999, interessado na captura das terras e águas nos baixões de Formosa do Rio Preto, com intuito de transformá-las em reserva legal. As comunidades geraizeiras enfrentaram por cerca de 20 anos violências e ameaças:

\begin{abstract}
Atiraram no meu esposo, prenderam meu cunhado, me agrediram; nosso território não é reserva do condomínio, estamos lá há mais de 300 anos. O Gerais é um lugar sagrado para nós. O oeste da Bahia pode ter alto potencial agrícola, mas antes de ser uma região de produção de grãos, é uma região de produção de água (Divanice das Chagas, 2019).
\end{abstract}

Nesse conflito, o Tribunal de Justiça da Bahia deu ganho de causa aos geraizeiros, em julho de 2020. Para Samuel Brito, agente pastoral da CPT, esse é "um marco da luta contra o agronegócio... saber que comunidades negras e pobres conseguiram essa vitória é de extrema relevância" (Brasil de Fato, 2020). 
O conflito socioambiental entre geraizeiros e a fazenda Estrondo exemplifica o que Bonfim e Vicente (2017, p. 15) afirmam: "a expropriação de águas e de terras, que alia violência e institucionalidade, e se baseia numa lógica extrativa, colonialista e racista de saqueamento e desconstituição social de territórios, é um dos motores centrais da acumulação capitalista".

Os conflitos de Correntina e da Fazenda Estrondo se constituem em marcos de luta e resistência, através da participação de movimentos e pastorais sociais que contribuíram para sua visibilização em escala nacional, potencializando os ganhos políticos. Esses processos sociais do campo estão mediados por relações assimétricas de poder marcadas pelo racismo ambiental, de origem moderno-colonial. A força dessas redes e ações coletivas trouxe um diferencial de ganho de poder no enfrentamento ao agronegócio e em conquistas, como sugere Acselrad (2002).

No contexto do conflito socioambiental, "a exposição desproporcional dos socialmente mais desprovidos aos riscos das redes técnico-produtivas da riqueza ou sua despossessão ambiental pela concentração dos benefícios do desenvolvimento em poucas mãos" (Acselrad, 2013, p. 109) reflete o caráter espoliativo do agronegócio em sua dimensão racista. O neoextrativismo está assentado sobre essa base de negação da legitimidade da cultura e do modo de vida tradicional e na violação dos processos sistêmicos da natureza, centrado que é em uma razão utilitária.

\subsection{O caso do Tocantins}

“(...) nós, as mulheres cerradeiras, nos posicionamos contra qualquer processo de destruição das fontes, contaminação e privatização das águas" (Carta do Primeiro Encontro de Mulheres do Cerrado, Junho, 2019).

Na Carta do Primeiro Encontro de Mulheres do $\mathrm{Cerrado}^{8}$, as mulheres se reconhecem como guardiãs dos saberes populares que vêm de longe, de seus e suas ancestrais, a partir dos quais as mulheres lutam e constroem e reconstroem seus diversos modos de vida desde seus territórios. São negras, indígenas, quilombolas, feministas, camponesas, assentadas e acampadas, sem-terra, atingidas por mineração e barragens, quebradeiras de coco babaçu, sertanejas, pescadoras, vazanteiras, LGBTQ+, assalariadas rurais, de fundo e fecho de pasto, raizeiras, benzedeiras, agricultoras familiares, geraizeiras, ribeirinhas (Carta, 2019).

"Ninguém vai morrer de sede nas margens dos nossos rios", afirmam elas, chamando a atenção para a importância das águas em seus territórios, que vêm sofrendo fortes impactos da expansão do agronegócio. Denunciam a destruição da vegetação, a expulsão de povos e comunidades, a contaminação das águas e das pessoas.

Essa delicadeza de reprodução da vida através dos rios; áreas alagáveis como os pântanos, brejos, lagos, lagoas e banhados; varjões; ipucas; interconectados nos Cerrados, é o ambiente regulador das águas da porção Sul do continente, incluindo os

\footnotetext{
${ }^{8}$ Carta do Encontro promovido pela Campanha Nacional em Defesa do Cerrado em junho de 2019. Mais informações da Carta do Primeiro Encontro das Mulheres do Cerrado estão disponíveis em: $<$ https://www.cptnacional.org.br/publicacoes/noticias/articulacao-cpt-s-do-Cerrados/4775-carta-do-i-encontro-nacional-das-mulheres-Cerrados>. Acesso em: ago. 2020.
} 
três grandes aquíferos alimentadores desse bioma que são o Urucuia, o Guarani e o Bambuí. Segundo Barbosa (2020a), essas águas que constituem, primordialmente, o ambiente mais antigo da história geológica recente do Planeta (período Cenozóico).

Os ecótonos ou áreas de transição dos Cerrados guardam grande importância de sucessão e permanência da paisagem em um mosaico de povos e comunidades tradicionais interatuantes nos territórios, configurando uma imensa diversidade. $\mathrm{Na}$ transição entre a Amazônia e o Cerrado, as regiões de áreas úmidas se destacam como ecótonos que são reconhecidos como áreas de patrimônio biológico mundial (Sales, 2018).

Na região hidrográfica Araguaia-Tocantins, as florestas inundáveis, mais conhecidas como ipucas, são fragmentos florestais naturais que ocorrem em região de ecótono entre o Cerrado e a Floresta Amazônica. O termo vem do Tupi - ipuka - e quer dizer "água arrebentada". Nessas florestas estão muitas espécies animais e vegetais, pois normalmente possuem água e umidade em seu solo para o consumo dos animais. As ipucas são áreas da planície aluvial da Ilha do Bananal que é periodicamente inundada pelas cheias dos rios, cuja função, nos períodos das cheias, é fazer a ligação entre os vários rios da região (Rodrigues, 2013). Segundo a Convenção sobre Diversidade Biológica, assinada pelo Brasil durante a Conferência das Nações Unidas sobre Meio Ambiente e Desenvolvimento (CNUMAD), em 1992, a Ilha do Bananal - a maior ilha fluvial do mundo - compõe com outras áreas o Sistema Ramsar para áreas úmidas de interesse internacional $^{9}$, sendo um importante sistema de várzea do rio
Araguaia com rios navegáveis de médio a alto porte, lagoas sazonais, pântanos e numerosas outras ilhas.

Vemos que o movimento das águas nessa região - a dinâmica das cheias e secas dos rios influencia os modos de vida e demarca o espaço coletivo das vidas das comunidades, em regime comunal, numa relação social de vivência respeitosa com as várzeas e os rios (Porto-Gonçalves, 2000). Esse modo de vida tradicional compõe uma diversidade de territórios tradicionais em suas mais variadas práticas:

O povo do Araguaia hoje é isso, é a mistura [...], é o povo ribeirinho, nós estamos impregnados com os ribeirinhos da nossa região, nós estamos impregnados com os posseiros da nossa região, porque tem filho de Kanela casado com posseiro, filho de Kanela casado com retireiro. Então, hoje os Kanelas do Araguaia vivem integrados a essas comunidades na região do Araguaia [...]. (Lenimar, oficina de mapas, Projeto Nova Cartografia Social da Amazônia, Manaus, 2009).

Assim, as florestas inundáveis, às margens desses rios e afluentes, são territórios de vida das populações indígenas, dos ribeirinhos e ribeirinhas, retireiras e retireiros e de diversos povos que ali desenvolveram e desenvolvem saberes e práticas baseados no uso comum (Porto-Gonçalves, 2000), com tradições variadas de manejos e produção das águas, dos recursos, e dos seus modos de viver.

O que é que nós chamamos de retiro aqui na região? Pessoas que têm um pouco de rebanho; retireiros são aquele povo que tem um pouco de gado e levam pra lá. Aquela área lá é alagadiça, no inverno, na época cheia enche tudo, e aí eles tiram o gado e levam para

${ }^{9}$ Mais informações disponíveis em: <https://rsis.ramsar.org/es/ris/624?language=es>. Acesso em: ago. 2020. 
o enxuto, onde não tem água. Quando é no verão, seca aquele lugar e fica muito bonito, tem lago, tem praia [...] então aqueles retireiros ajuntam todos, levam seu gado pra aquele retiro...Como é baixo, no verão nasce aquele capim bonito, quando seca é úmido, no verão mantém aquele pasto, então eles levam o gado de volta, depois traz o gado de volta, aí fica. Isso que nós chama de retireiro. Igual no meu caso, eu retiro na Ilha do Bananal, então sou retireiro da Ilha do Bananal. (Lenimar, oficina de mapas, Projeto Nova Cartografia Social da Amazônia, Manaus, 2009).

No estado do Tocantins, em geral, podemos dizer que a predominância de seu território corresponde ao bioma Cerrado com área de mais de $60 \%$ e o restante se constitui de fragmentos de florestas, como as Ipucas, que guardam muita diversidade e podem ser identificadas quase sempre nas Bacias do Tocantins, Araguaia, Paranã e afluentes. A bacia hidrográfica Araguaia-Tocantins é a maior bacia localizada dentro do território nacional brasileiro, com aproximadamente 2.500 quilômetros desde sua origem, que se dá no encontro dos rios Maranhão com o rio das Almas, em Goiás, até sua foz na baía de Marajó, no Pará. Essa região possui 11 sistemas aquíferos: Alter do Chão; Bambuí; Barreiras; Cabeças, Corda, Furnas; Guarani; Itapecuru; Motuca; Ponta Grossa e Urucuia-Areado, que somam uma reserva de 9.254 milhões de metros cúbicos de água por ano (MMA, 2006). Os rios Araguaia e Tocantins compõem com suas bacias essa grande e importante região hidrográfica. Araguaia, embora pouco considerado nos estudos sobre os grandes rios do Planeta, é o décimo primeiro rio do mundo em vazão (Seplan, 2016).

Essa região de águas correntes e transbordantes foi área de implementação de grandes projetos de irrigação e barragens, especialmente para o cultivo de arroz e outros grãos como milho e soja. A água para a irrigação do monocultivo de arroz nessa região corresponde a $66 \%$ da demanda total e se concentra na sub-bacia do Araguaia e seus afluentes (MMA, 2006).

Nesse sentido, é importante destacar a região do médio Araguaia-Tocantins, cuja característica de planície, sistemicamente, apresenta inundações sazonais nas estações seca e chuvosa. Esse movimento das águas é o responsável por controlar as variações de descarga dos rios que, no caso do rio Araguaia, é de aproximadamente 2.644 metros cúbicos por segundo ao ano, sendo a descarga de transbordamento média de 6.654 metros cúbicos por segundo (Seplan, 2016). Essa região, ademais, por conta de suas características hidrogeológicas, é um grande reservatório de águas subterrâneas que são vistas pelo agronegócio como ideais para a expansão de projetos de irrigação. Neste sentido, é importante ressaltar as cabeceiras do Rio Araguaia, nos municípios de Formoso do Araguaia e Lagoa da Confusão, para as áreas de expansão do agronegócio com seus projetos em larga escala.

Destacamos aí o Projeto Rio Formoso, implementado no ano de 1979, ligado ao programa de desenvolvimento estatal Prodecer, como áreas agrícolas irrigadas em médias e grandes propriedades, com investimentos públicos e privados, revelador de como o agronegócio se territorializa e produz espoliação das águas na região (Rodrigues, 2013). $\mathrm{O}$ avanço da fronteira agrícola nessa região sempre se serviu e serve da abundância de recursos hídricos, com solos hidromórficos, localizados sobre as várzeas e as ipucas, e que permitem a realização de duas safras diferentes de grãos por ano, arroz e soja, com elevados índices de produtividade, em modelo produtivo baseado na mecanização, manipulação 
genética de sementes e utilização de grande quantidade de agrotóxicos.

Esse Projeto de Irrigação foi o pioneiro ao utilizar sistemas de irrigação do tipo inundação em uma área inicial de 27 mil hectares para o cultivo de arroz irrigado, no período chuvoso, e de soja (para a produção de sementes) no período da seca. A infraestrutura desse Projeto incluiu a construção de diques, reservatórios, canais de adução e irrigação e de drenagem, todos ligados diretamente a fortes impactos nos rios. As obras foram realizadas em etapas nos anos de 1979; 1980 e 2003, ampliando cada área em 11.900 hectares (Rodrigues, 2013). A Figura 6 bem demonstra esses canais de irrigação cuja principal finalidade é, através de barramentos, capturar e desviar uma grande quantidade de água do curso original do rio para os monocultivos em larga escala, impactando diretamente o fluxo e vazão das águas dos rios e a contaminação dessas águas.
A implantação desse empreendimento resultou em intensos conflitos entre os fazendeiros e os povos e comunidades que tradicionalmente viviam e vivem na região, causando fortes impactos nos territórios das populações indígenas como os Bororo e os Xavante, nos rios Araguaia e das Mortes; os Inã e Karajá, que juntamente com os Javaé, vivem às margens do rio Araguaia e de seus afluentes. A esses povos também se juntam os Tapirapé, e, ainda, no vale do Tocantins, temos a presença dos Xerente, Krahô, Apinajé e Krikati (Porto-Gonçalves, 2000).

Estudos de 2006 apontam ampliação de mais 33.000 hectares da área irrigada no rio Formoso, sendo que, destes, 28.000 hectares destinados ao arroz e à soja; e também em seus afluentes: 22.000 hectares no rio Urubú e 160.000 hectares para arroz no rio Javaés (MMA, 2006).

Esses Sub-Projetos mais recentes estão localizados em sub-bacias do rio Formoso - como a do rio Escuro, do rio Pau Seco, do ribeirão Lago Verde,

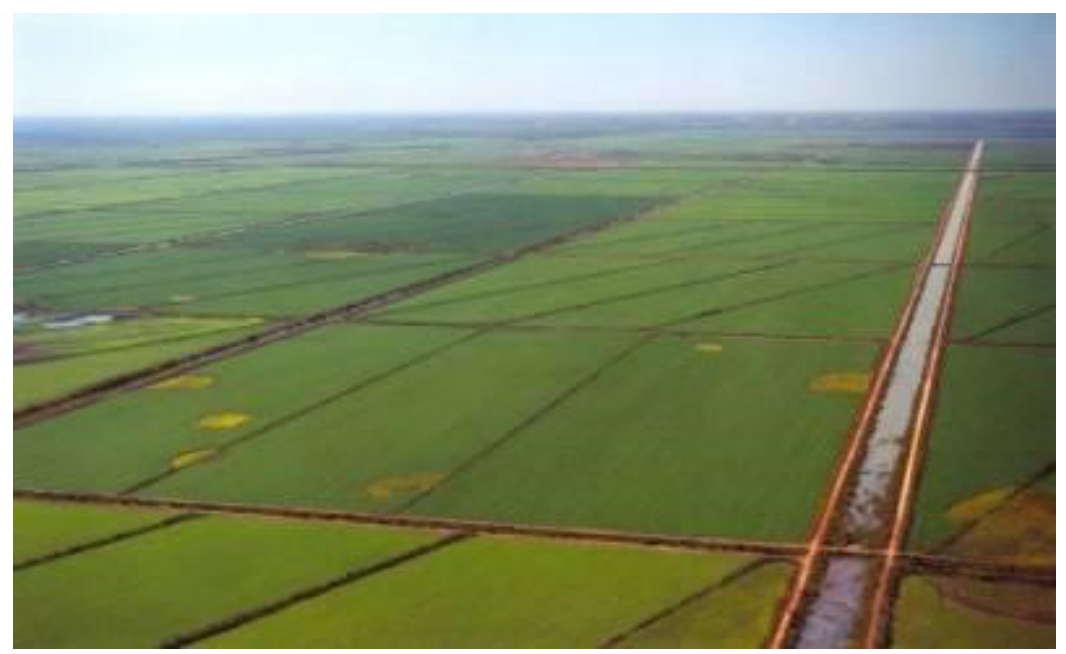

FIGURA 6 - Extensos canais de captura das águas do rio Formoso na área de irrigação, Formoso do Araguaia. FOTO: Angélica Mendonça / Secom / Seagro-TO (2011). 
do ribeirão da Taboca, do rio Urubu, do rio Dueré, do rio Xavante - e em sua principal sub-bacia, a do rio Javaés, que corresponde a $5,6 \%$ da bacia do Araguaia (Seplan, 2016). A sub-bacia do Javaés está margeada ao rio Araguaia, nasce na Serra dos Caiapós e ao norte conflui ao rio Tocantins, formando nesse centro a extensa ilha do Bananal, com 350 quilômetros de comprimento e 60 quilômetros de largura, alagada em sua maior parte. A Figura 7 ilustra os campos irrigados com seus canais de irrigação margeando o rio Formoso.

Essa imagem bem expressa o que denunciam recorrentemente as comunidades tradicionais que vivem às margens desse rio sobre os graves impactos do processo intenso de barramento e captura das águas para a irrigação do monocultivo de arroz sobre os rios: assoreamento, diminuição do volume do fluxo das águas e até seca ou morte de trechos do rio, como esquematizado na Figura 8.

O Projeto Rio Formoso é ainda limítrofe ao Parque Indígena do Araguaia (PIA) e ao entorno do Parque Nacional do Araguaia (PARNA), onde o avanço do agronegócio tem contribuído para sistemáticas retiradas de enormes volumes de água dos rios Formoso e seu afluente Javaés, que são parte essencial dos meios e modos de vida das populações tradicionais da região, além de possuírem valor simbólico e cultural. Os modos de vida das etnias indígenas Javaés e Karajás, ligados diretamente a essas águas, sofrem impactos constantes. Contudo, cabe salientar que essa região remonta também ao território de outras etnias, como os Avá-Canoeiros,

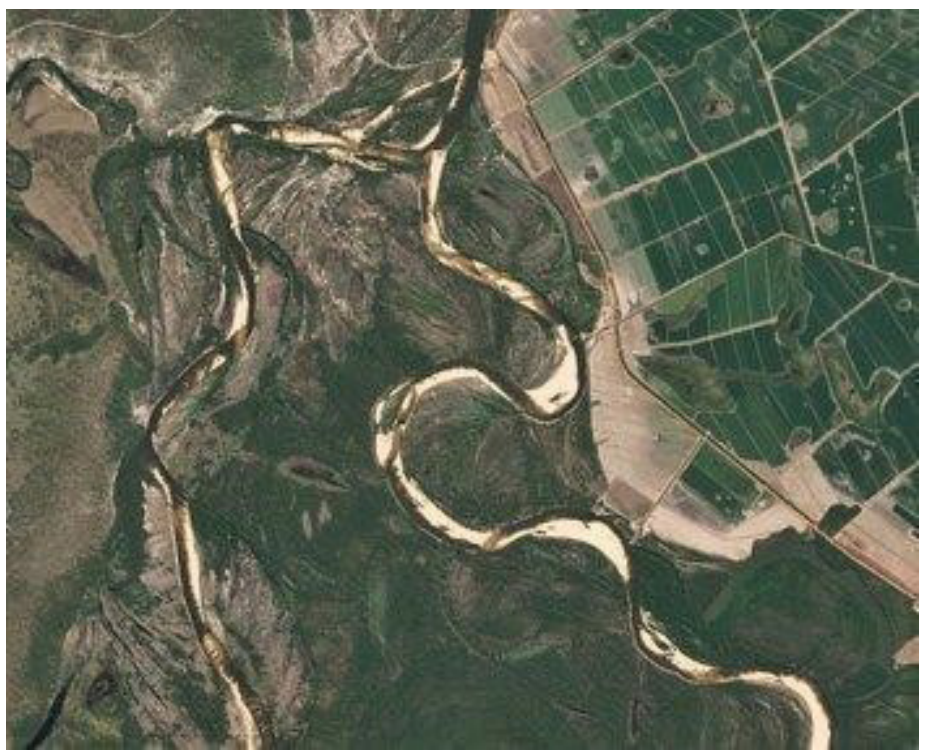

FIGURA 7 - Imagem de satélite contrastando as áreas irrigadas margeadas ao leito do rio com pontos de assoreamento e intenso desmatamento da vegetação de suas margens (galerias).

FOTO: Jornal Conexão Tocantins (2018). 


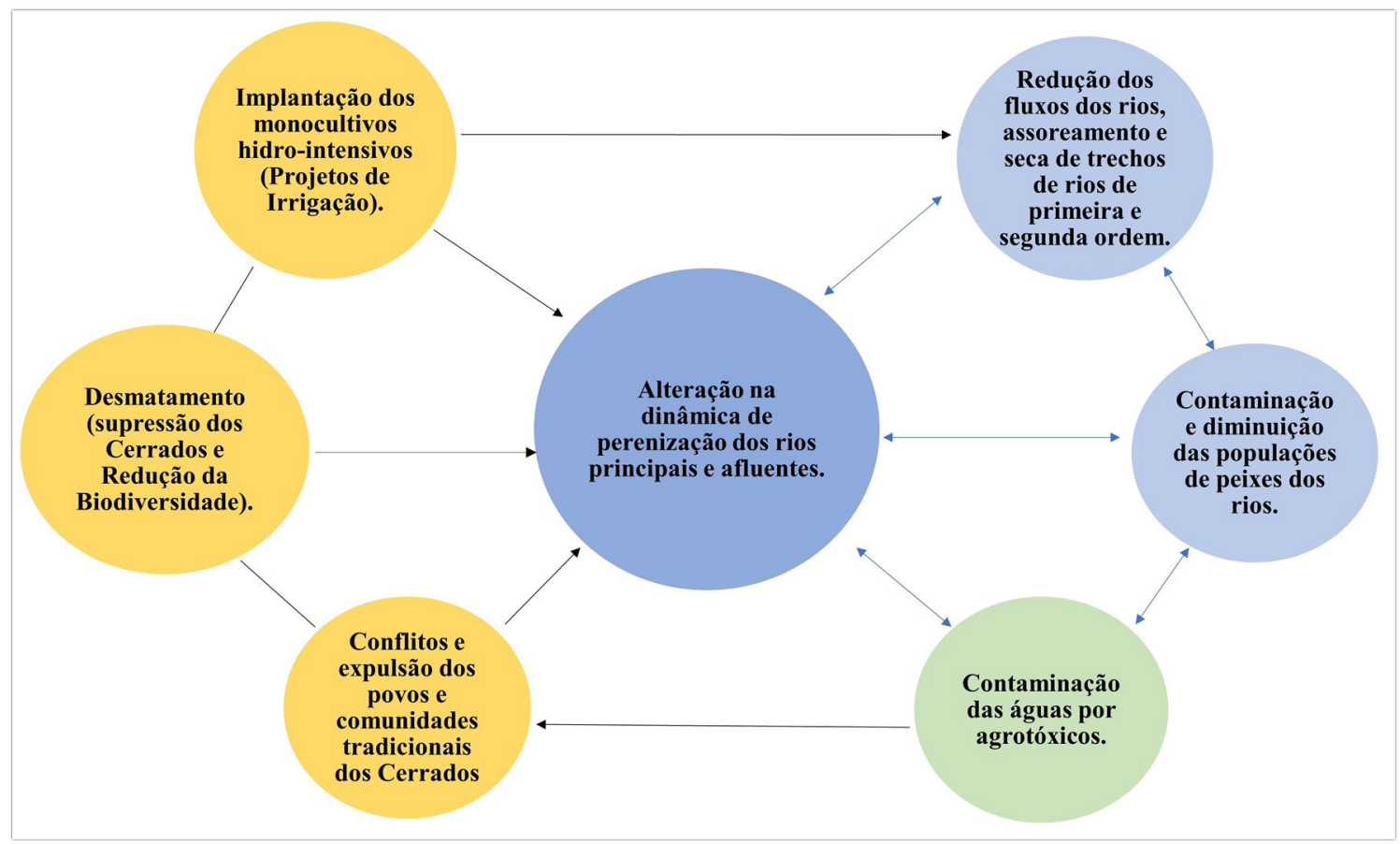

FIGURA 8 - Processos de Espoliação das Águas pelo Agronegócio no Tocantins

Xavante, Xambioás e Xerente, que perderam paulatinamente parte de seus territórios para o avanço do agronegócio (Rodrigues, 2013).

Nas últimas duas décadas, empresas multinacionais ligadas ao setor de produção de grãos conformam mais uma importante e grave etapa do processo de expansão do agronegócio. Essas empresas têm se aproveitado de forma predatória da região, apropriando-se de suas águas e solos de boa qualidade para o plantio irrigado, fazendo das várzeas e nas ipucas do entorno da Ilha do Bananal um dos maiores polos produtores de sementes transgênicas de soja do Brasil (Rodrigues, 2013).
Ainda mais recentemente podemos considerar o processo de "revitalização" do Projeto Rio Formoso como mais uma etapa de expansão da produção de grãos, implementada pelo governo federal em 2011, como um dos maiores investimentos realizados pelo PAC (Plano de Aceleração do Crescimento) na agricultura irrigada em todo país. Essa fase faz do rio Formoso o de maior número de outorgas de água para irrigação do estado Tocantins.

As ipucas, os varjões, os rios, as populações e todo ecossistema da planície são gravemente afetados pela espoliação das águas promovida pelo agronegócio. Em 2016, uma severa seca no rio Javaés expôs um dos graves impactos da expansão 
desse tipo de irrigação - a crise hídrica ${ }^{10}$ caracterizada pela baixa de volumes dos rios e consequente seca de quilômetros do rio Javaés, como podemos ver na Figura 9.

A intensa e ancestral resistência dos povos e comunidades tradicionais, indígenas, camponeses, vazanteiros e ribeirinhos dessa Ilha, com a defesa de seus territórios e modos de vida, cumpre o papel de barreira ao avanço intenso das fronteiras agrícolas em direção ao PIA e ao PARNA, na Ilha do Bananal, gerando, contudo, numerosos conflitos. As comunidades tradicionais dessa região terminam tendo seus modos de vida impactados pelo agronegócio e sendo forçadas de forma violenta a abandonar as práticas comunitárias comuns e de gestão e manejo de seus territórios em regime comunal. A expansão do agronegócio e a espoliação das águas impedem as comunidades de se relacionarem com o movimento das águas, que demarca o ritmo de suas vidas nos territórios. Ademais, outro conflito extremamente importante, também relacionado aos "usos" das águas pelo agronegócio dentro da bacia do Rio Formoso, diz respeito ao uso intensivo de agrotóxicos, que poluem o leito dos rios, atingindo

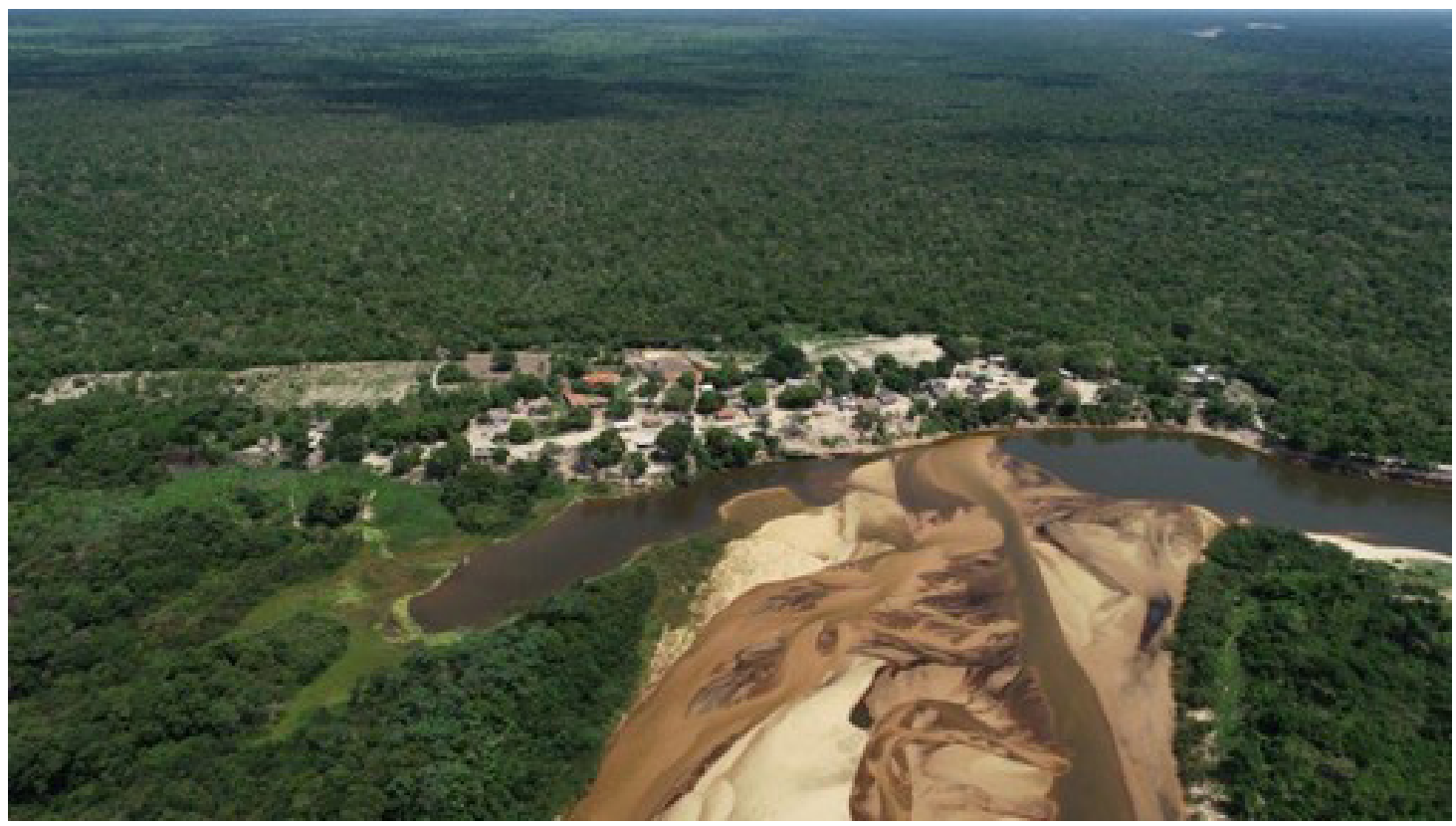

FIGURA 9 - Aldeia Boto Velho, do povo Javaé, na Terra Indígena Inãwébohona, Ilha do Bananal sob os impactos da seca do rio Javaés. FONTE: Cimi Regional Goiás/Tocantins (2016).

\footnotetext{
${ }^{10}$ Várias notícias são veiculadas na mídia mostrando o stress hídrico do rio Javaés, indicando a morte do rio, bem como da bacia do rio Formoso, com participação direta do Ministério Público do Tocantins na suspensão das outorgas de água. Mais informações disponíveis em: <https:// conexaoto.com.br/2018/06/13/atuacao-do-ministerio-publico-na-protecao-da-bacia-hidrografica-do-rio-formoso-e-destaque-em-revista-nacional-sobre-sustentabilidade > e <http:/www.oprogresso.net/tocantins/justica-proibe-captacao-de-agua-na-bacia-do-rio-formoso-decisao-atinge-18-propriedades/118225.html>. Acesso em: set. 2020.
} 
as comunidades localizadas no entorno do projeto de agricultura irrigada, caso das comunidades indígenas Javaés e Karajá que têm sua alimentação baseada, entre outros alimentos, nos peixes retirados dos rios e lagoas.

\section{O modelo produtivo do agronegócio: agrotóxicos, adoecimento e morte}

Além das questões relacionadas aos usos das terras e das águas, que compõem as transformações territoriais realizadas pelo agronegócio nos Cerrados, há ainda uma outra dimensão de seu modelo produtivo que provoca conflitos e contribui para o ecocídio do bioma, qual seja o intensivo uso de agrotóxicos.

$\mathrm{O}$ uso de agrotóxicos e suas consequências à saúde e ao ambiente são temas discutidos mundialmente. Nas últimas décadas, têm sido frequentes, no Brasil, as publicações que apresentam resultados evidenciando as relações entre a contaminação ambiental e humana por agrotóxicos, a exposição a essas substâncias e o surgimento de diversas doenças. Os métodos para detectar os agrotóxicos no ambiente, nos alimentos, na água e nas populações expostas, na grande maioria das vezes, não são disponíveis para os sistemas de Vigilância em Saúde dos municípios brasileiros, apesar de a sistematização de dados sobre o uso de agrotóxicos e o adoecimento das pessoas ser fundamental para fomentar discussões que gerem ações protetivas nos territórios que sofrem com o uso intensivo de agrotóxicos.

Uma das formas de obter dados sobre produção agrícola é por meio do Banco de Produção Agrícola Municipal-PAM, do Sistema de Recuperação Automática (SIDRA) do Instituto Brasileiro de Geografia e Estatística IBGE (IBGE, 2020). Os dados de esti- mativa de uso de agrotóxicos podem ser obtidos pela metodologia de Pignati et al. (2017), que multiplica a quantidade de agrotóxicos utilizada por hectare de plantação, em 21 cultivos (que foram selecionados pelas informações sobre a quantidade de uso de agrotóxicos por hectares). Nesse trabalho, foram considerados dados de quatro cultivos, sendo eles algodão, cana-de-açúcar, milho e soja. O principal critério para seleção desses cultivos foi a predominância deles como commodities agrícolas mais relevantes em termos econômicos para o agronegócio brasileiro, em expansão na região do Cerrados. Além das informações sobre esses cultivos, optou-se por sistematizar também os dados sobre pastagem, tendo em vista a enorme presença do setor produtivo da agropecuária na economia brasileira, e, por consequência, a grande exploração de terras que essa atividade exige. Os dados de pastagem foram obtidos pela plataforma de informações sobre pastagem do Laboratório de Processamento de Imagens e Geoprocessamento da Universidade de Goiás - Lapig/UFG (LAPIG, 2020).

A seleção dos municípios caracterizados como pertencentes ao bioma Cerrados considerou o conceito de regiões de transição do Cerrados elaborado pelo Laboratório de Estudos de Movimentos Sociais e Territorialidades da Universidade Federal Fluminense (LEMTO/ UFF), o qual elevou o número de municípios do Cerrados de 1.112, de acordo com a classificação tradicional do IBGE, para $1.967 \mathrm{mu}-$ nicípios, ao incluir as zonas de transição do bioma Cerrados com outros biomas (Amazônia, Pantanal, Caatinga e Mata Atlântica).

Além da sistematização das principais informações sobre a extensão das áreas plantadas e o consumo de agrotóxicos nos municípios selecionados, em relação aos cultivos elencados e à pastagem, foi realizada uma revisão bibliográfica, em bases que 
reúnem pesquisas na área de saúde, que envolveu três grupos de agravos relacionados à exposição aos agrotóxicos: agravos agudos (intoxicação exógena por agrotóxicos), subagudos (más-formações congênitas) e crônicos (câncer infanto-juvenil). Os dados sobre os agravos de saúde foram obtidos no Departamento de Informática do SUS - DATASUS (MS, 2020), do Ministério da Saúde, no Sistema de Informação de Agravos e Notificação (SINAN), no Sistema de Informação sobre Nascidos Vivos (SINASC) e no Sistema de Informação sobre Mortalidade (SIM). Optou-se por trabalhar com esses três grupos de agravos com o intuito de apresentar e discutir a variedade de consequências à saúde ocasionadas pelo tempo de exposição aos agrotóxicos.

Para os dados sobre Intoxicação Exógena, foram selecionados agrotóxicos (agrícola, doméstico, saúde pública e raticida) na população com faixa etária entre 15 e 59 anos, por ser economicamente ativa, entre os anos 2016 e 2017. Em relação aos dados de más-formações congênitas, foram selecionados os nascimentos por local de residência da mãe, entre os anos 2017 e 2018. Os dados sobre câncer infanto-juvenil referem-se aos óbitos por local de residência, na faixa etária entre 0 e 19 anos, nos anos de 2017 e 2018. O cálculo das taxas médias de cada agravo foi realizado a partir da seguinte razão: no numerador, a média do número de casos ou óbitos, de acordo com o período estudado para cada município, dividido pela média dos anos estudados; no denominador, a média populacional do município nos anos estudados. Posteriormente, os valores foram multiplicados por uma constante, que representa o número de habitantes.

As intoxicações exógenas agudas (efeitos a curto prazo) por agrotóxicos foram selecionadas por representarem o grupo de agravos que, apesar de todas as limitações dos sistemas de informação, apresentam uma regularidade de notificação bem superior aos agravos crônicos (efeitos a longo prazo). Apesar de haver um processo grave de subdiagnóstico e subnotificação dos agravos subagudos e crônicos relacionados à exposição aos agrotóxicos, o que dificulta sobremaneira as análises e sistematização das informações a respeito desses grupos de agravos, optou-se por discuti-los no presente artigo pela relevância deles em termos de saúde pública e pela abundância de estudos e pesquisas que relacionam esses agravos à exposição aos agrotóxicos.

As más-formações congênitas foram selecionadas no grupo dos agravos subagudos (efeitos a médio prazo) tanto por existirem evidências científicas confiáveis que corroboram as relações entre elas e a exposição aos agrotóxicos como, também, pelas denúncias e pelos relatos crescentes de populações afetadas pelo agronegócio a respeito da percepção de que a prevalência desses agravos tem crescido bastante em seus territórios nos últimos anos (Aguiar, 2017).

O câncer infanto-juvenil foi selecionado como representante dos agravos crônicos também pelas robustas evidências do campo científico a respeito da exposição aos agrotóxicos como um importante fator responsável pelo surgimento de neoplasias. Além disso, por se tratar de uma doença multifatorial, optou-se por fazer um recorte da faixa etária infanto-juvenil pelo reconhecimento de que os fatores ambientais são muito relevantes no desencadeamento de câncer nessa população (Belpomme et al., 2007).

\subsection{Agronegócio, exposição aos agrotóxicos e efeitos negativos à saúde}

O uso de agrotóxicos nas lavouras agrícolas é praticado em todos os estados brasileiros e tem trazido 
consequências negativas ao ambiente e à saúde das pessoas. Nas últimas décadas, têm-se acumulado evidências científicas e pronunciamentos de instituições públicas a respeito dos impactos do modelo produtivo do agronegócio e do uso de agrotóxicos. Algumas regiões do país são particularmente ameaçadas e afetadas pelas atividades intensivas do agronegócio nos seus territórios, como os Cerrados brasileiros, que têm sido sistematicamente invadido por projetos direcionados à produção de commodities.

Apesar de toda a população brasileira, em maior ou menor grau, estar potencialmente exposta aos agrotóxicos, é reconhecida a enorme vulnerabilização de determinados setores da sociedade, como os/as trabalhadores/as que manejam direta ou indiretamente essas substâncias e as comunidades que vivem no entorno das lavouras onde são pulverizados ou produzidos os agrotóxicos. Essas populações, que sofrem historicamente violações de direitos humanos e são desprovidas do acesso a políticas públicas protetivas, tornaram-se as principais atingidas pela ascensão do agronegócio e do uso de agrotóxicos no Brasil. Em 2018, houve a publicação de um importante relatório produzido pela organização Human Rights Watch, intitulado "Você não quer mais respirar veneno - As falhas do Brasil na proteção de comunidades rurais expostas à dispersão de agrotóxicos" "11, que sistematizou diversas informações a respeito do sofrimento e adoecimento das comunidades rurais expostas aos agrotóxicos no Brasil.
As populações mais vulnerabilizadas pela pulverização de agrotóxicos no Brasil são formadas por povos originários e comunidades tradicionais, como indígenas, quilombolas e agricultores/as familiares. A situação agrava-se sobremaneira com a prática, ainda permitida pela legislação brasileira, da pulverização aérea de agrotóxicos. Muitas comunidades têm denunciado o uso criminoso dessa atividade. Nos últimos anos, houve grandes "acidentes" envolvendo a pulverização aérea de agrotóxicos no Brasil, um dos mais lamentáveis ocorreu na cidade de Rio Verde $(\mathrm{GO})^{12}$

As intoxicações agudas causadas por agrotóxicos representam um grave problema de saúde pública no Brasil. Os dados oficiais obtidos pelos principais sistemas de informação em saúde do país (Centro de Informações Toxicológicas, SIM e SINAN) mostram que a cada 100 intoxicações por agrotóxicos, quatro evoluem para óbito, predominando entre as circunstâncias dessas intoxicações exógenas as tentativas de suicídio. Além disso, observa-se a maior incidência de intoxicações exógenas causadas por agrotóxicos em trabalhadores rurais do sexo masculino (Magalhães \& Caldas, 2019; Bochner \& Freire, 2020; Okuyama et al., 2020). Outros estudos também demonstram que o risco de morte por intoxicação é 2,5 vezes maior em homens do que em mulheres, concentrando-se na região Centro-Oeste a maior taxa de mortalidade (Bochner \& Freire, 2020). É possível constatar também que a incidência de intoxicação segue uma tendência de aumento, principalmente na região Sul e Centro-Oeste, porém o maior incremento

\footnotetext{
${ }^{11} \mathrm{O}$ relatório está disponível em: <https://www.hrw.org/sites/default/files/report_pdf/brazil0718port_web2.pdf>. Acesso em: nov. 2020.

${ }^{12}$ Pulverização aérea sobre a escola rural São José do Pontal, atingindo 90 pessoas, a maior parte composta por crianças que estudavam na escola. Um documentário sobre este caso intitulado "Pontal do Buriti - Brincando na chuva de veneno" está disponível em: $<$ https://youtu.be/ qHQdWwZcGlg>. Acesso em: jan. 2021.
} 
anual médio está na região Centro-Oeste (Queiroz et al., 2019).

Em Goiás, Neves et al. (2020) identificaram que há um aumento de intoxicações por tentativa de suicídio. As regiões que mais notificam intoxicações por agrotóxicos são áreas onde predomina o modelo produtivo do agronegócio, nas quais houve um aumento de notificações por intoxicações causadas por herbicidas (Roundup, Furadan, 2,4-D, Regent, Aldrin e Furazin, respectivamente). No estado do Mato Grosso, Silva et al. (2019) encontraram correlações positivas entre moradores cujas residências localizam-se próximas às lavouras de milho e algodão e uma maior incidência de intoxicações agudas, quase duas vezes superior a moradores de outras regiões.

Em relação às intoxicações exógenas por agrotóxicos como possíveis causas de suicídios, um recente estudo conduzido pela Universidade Federal da Bahia (UFBA) demonstrou que, entre os anos 2007 e 2015, a maior mortalidade por suicídios, no Brasil, ocorreu em trabalhadores da agropecuária ${ }^{13}$. Assim, para que haja uma compreensão sobre esse importante achado, é necessário, além de avaliar o processo crescente de precarização da vida no campo, também considerar o uso indiscriminado de agrotóxicos, incentivado por políticas públicas, como um dos fatores que pode estar envolvido nesse alto índice de suicídios entre os trabalhadores da agropecuária.

A média de intoxicação exógena, nos anos 2016 e 2017, no Brasil, foi de 6,8 para cada 100.000 habitantes. Nos Cerrados, essa taxa foi de 8,5 para cada 100.000 habitantes, conforme apresentado na Figura 10.

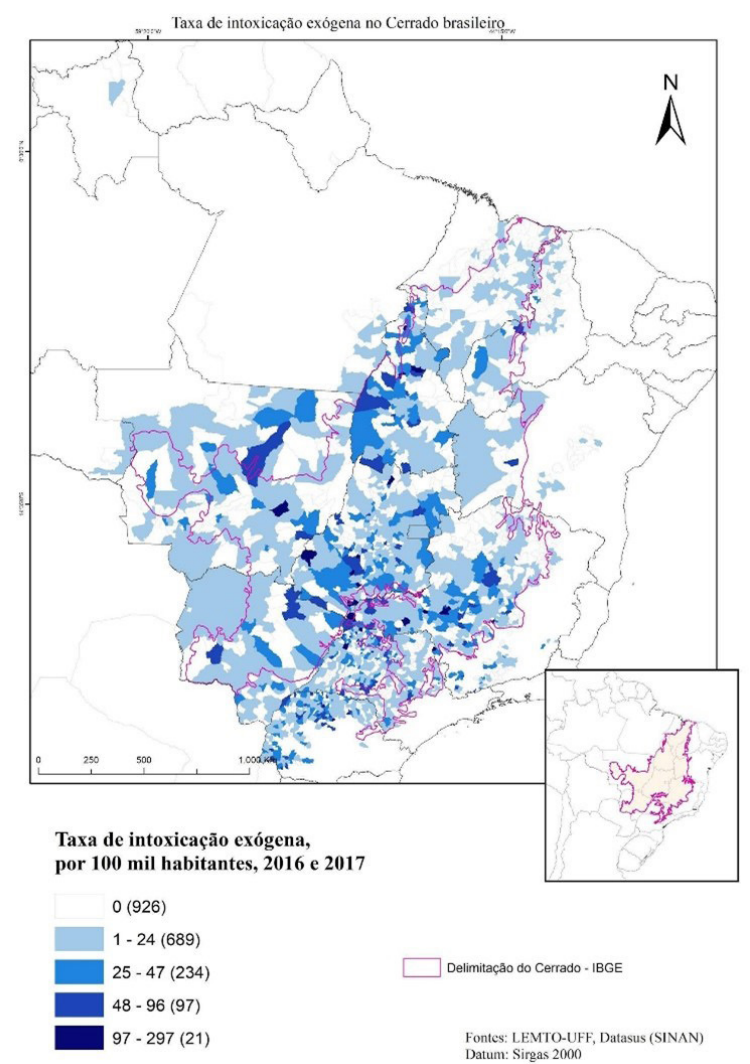

FIGURA 10 - Taxa média de intoxicações exógenas por agrotóxicos, em municípios dos Cerrados brasileiros, ano 2017.

Em relação às más-formações congênitas, Mostafalou e Abdollahi (2016) realizaram uma ampla revisão sistemática da literatura, em âmbito internacional, e selecionaram estudos científicos com elevado grau de evidência em relação à exposição aos agrotóxicos e o desencadeamento de más-formações congênitas, como: diminuição da circunferência craniana (Chevrier et al., 2011;

${ }^{13}$ Boletim epidemiológico disponível em: <http://www.ccvisat.ufba.br/wp-content/uploads/2019/08/SUICIDIO_BOLETIM_CCVISATfinalFINAL.pdf>. Acesso em: jan. 2021. 
Gemmillet et al., 2013); más-formações congênitas (Siqueira et al., 2010); defeitos do tubo neural (Brender et al., 2010; Ren et al., 2011); e aumento do risco de espinha bífida (Makelarski et al., 2014).

Estudo ecológico realizado no estado do Paraná, que analisou as taxas de más-formações congênitas entre os anos de 1994 a 2003 e de 2004 a 2014, mostrou uma tendência crescente nas taxas de más-formações congênitas no estado do Paraná, mais notável nos municípios com maior uso de agrotóxicos (Dutra \& Ferreira, 2019). Ainda no Paraná, pesquisa realizada por Freire et al. (2020), com a finalidade de analisar as correlações entre os nascimentos com más-formações congênitas, entre os anos 2008 e 2015, e alguns indicadores sociais, econômicos, de atenção à saúde e ambientais, comprovou uma associação significativa $(\mathrm{p}<0,05)$ entre as más-formações congênitas e o consumo de agrotóxicos no estado.

Outro estudo ecológico realizado nos estados do Sul e Sudeste do Brasil investigou as relações entre as taxas de mortalidade infantil causadas por más-formações congênitas do sistema nervoso central e cardiovasculares, em lactentes menores de 1 ano (entre os anos de 1986-1990 e 19972001 , respectivamente) e o consumo per capta de agrotóxicos (entre os anos de 1985 e 1996), nas microrregiões desses estados. A pesquisa evidenciou a presença de correlações significativas e positivas entre o consumo de agrotóxicos per capita e as taxas de mortalidade por defeitos do sistema nervoso central e cardiovasculares em microrregiões rurais, mas não em áreas urbanas (Cremonese et al., 2014).

Dutra e Ferreira (2019) realizaram uma estimativa sobre o uso de agrotóxicos em quatro estados brasileiros que ocupam os primeiros lugares na produção de commodities agrícolas (São Paulo, Mato Grosso, Paraná e Rio Grande do Sul) e suas microrregiões, e compararam essas informações com a prevalência de más-formações congênitas nesses estados e nas suas microrregiões, por meio de um estudo ecológico de análise temporal sobre a prevalência de más-formações congênitas, entre os anos 2000 e 2016 . O estudo analisou a produção agrícola e o consumo de agrotóxicos nesses estados em quatro cultivos principais (algodão, cana-de-açúcar, milho e soja) e concluiu que as taxas de más-formações congênitas nas microrregiões dos estados que apresentavam maiores produções de grãos foram mais elevadas.

Com relação às pesquisas sobre más-formações congênitas e exposição aos agrotóxicos nos municípios que fazem parte do Bioma Cerrados, estudo do tipo caso-controle, realizado no estado do Mato Grosso, com a finalidade de pesquisar as relações entre exposição paterna aos agrotóxicos e a ocorrência de más-formações congênitas em crianças menores de 5 anos atendidas nos hospitais da cidade de Cuiabá (públicos e privados), no ano de 2011, encontrou uma associação positiva entre o trabalho do pai relacionado à agricultura $(\mathrm{OR}=$ 4,65, IC 95\%: 1,03-20,98) e a exposição paterna pregressa aos agrotóxicos (OR $=4,15$, IC 95\%: 1,24-13,66) com a ocorrência de más-formações congênitas (Ueker et al., 2016).

Os dados sobre más-formações congênitas mostram que a taxa média de más-formações congênitas, nos anos 2017 e 2018, no Brasil, foi de 8,7 para cada 1.000 nascidos vivos. Nos Cerrados, foi de 7,4 para cada 1.000 nascidos vivos, conforme apresentado na Figura 11. 


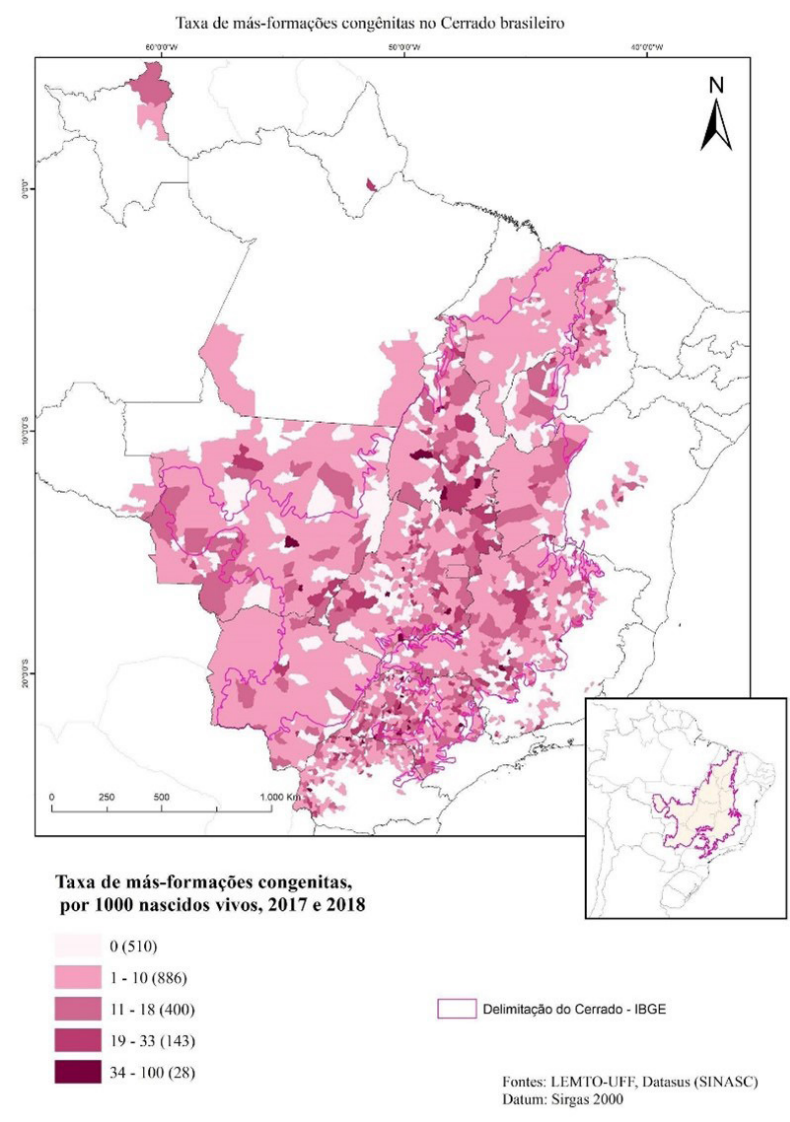

FIGURA 11 - Taxa média de más-formações congênitas, em municípios dos Cerrados brasileiros, ano 2018.

É necessário analisar essas taxas de másformações congênitas, assim como as demais aqui mencionadas, a partir de uma perspectiva crítica. Elas são elaboradas a partir de dados sobre as macrorregiões, sendo a prevalência do agravo considerada sobre o denominador de toda a sua população. Entretanto, tais indicadores podem não refletir o que de fato está ocorrendo no perfil de adoecimento dos/as trabalhadores/ as dos empreendimentos agrícolas e nem das populações que estão em seu entorno imediato, onde se concentra o risco de contaminação, caracterizando verdadeiras zonas de sacrifício. É o que demonstram muitos estudos que investigam esses agravos e a relação deles com a exposição aos agrotóxicos utilizando como fonte de informações as microrregiões, pois sabe-se que a pulverização de agrotóxicos concentra-se em alguns territórios específicos, de acordo com a distribuição espacial das plantações de commodities. Por isso, muitas vezes, analisar os indicadores de saúde a partir de uma perspectiva municipal ou regional pode diluir essas informações e corroborar com o processo de invisibilização desses agravos.

São abundantes e crescentes as evidências científicas sobre as relações entre a exposição aos agrotóxicos e o desencadeamento de diversos tipos de câncer. No ano de 2015, o Instituto Nacional de Câncer (INCA), a principal instituição brasileira voltada à produção de conhecimentos acadêmicos sobre essa temática, publicou uma nota técnica intitulada Posicionamento do Instituto Nacional de Câncer José Alencar Gomes da Silva acerca dos Agrotóxicos, na qual reúne uma série de evidências a respeito do uso de agrotóxicos no Brasil como um importante fator ambiental para o surgimento de numerosas neoplasias ${ }^{14}$.

Um dos agrotóxicos mais utilizados no Brasil e no mundo, o herbicida glifosato, foi classificado pela Agência Internacional de Pesquisas em Câncer (Iarc), da Organização Mundial da Saúde (OMS), como provável cancerígeno humano (grupo $2 \mathrm{~A}$ )

\footnotetext{
${ }^{14}$ Posicionamento do INCA sobre agrotóxicos disponível em: <https://www.inca.gov.br/publicacoes/notas-tecnicas/posicionamento-do-inca-acerca-dos-agrotoxicos>. Acesso em: jan. 2021.
} 
(OMS, 2015). Desde o ano 2019, o glifosato está passando por um processo de reavaliação no Brasil, comandado pela Agência Nacional de Vigilância Sanitária (Anvisa), do Ministério da Saúde. Como contribuição técnica ao processo de reavaliação, a Associação Brasileira de Saúde Coletiva (Abrasco) produziu o documento intitulado Parecer Técnico sobre processo de reavaliação do ingrediente ativo de agrotóxico glifosato utilizado na agricultura e como produto domissanitário ${ }^{15}$

Uma revisão integrativa realizada por Costa et al. (2017) sistematizou os principais estudos a respeito da carcinogenicidade de determinados ingredientes ativos de agrotóxicos em relação ao linfoma não Hodgkin (LNH) e concluiu que existem evidências suficientes que associam os ingredientes ativos ácido diclorofenoxiacético (2,4-D), diazinona, glifosato e malation ao surgimento de LNH.

Outro estudo, que realizou uma revisão sistemática da literatura científica internacional sobre neoplasias hematológicas e exposição ocupacional aos agrotóxicos organofosforados, comprovou que o risco do aparecimento de cânceres hematológicos aumenta com a exposição ocupacional a organofosforados, principalmente nos trabalhadores com histórico de exposição durante períodos mais elevados (Moura et al., 2020).

Pesquisa realizada por meio de uma revisão integrativa sobre exposição aos agrotóxicos e sua relação com determinados tipos de câncer encontrou evidências significativas entre câncer de próstata, linfoma não-Hodgkin, leucemia, mieloma múltiplo, câncer de bexiga e câncer de cólon e a exposição aos agrotóxicos, sendo que o risco é aumentado para pessoas que residem próximas a plantações ou em áreas densamente agrícolas, e também em agricultores/as (Pluth et al., 2019).

Em relação ao câncer infanto-juvenil, pesquisa realizado por Silva et al. (2018), em um polo de fruticultura irrigada no Nordeste brasileiro para avaliar as tendências da morbimortalidade por câncer infanto-juvenil, concluiu que, nos municípios estudados (Petrolina e Juazeiro, Pernambuco), houve tendência de aumento significante das taxas de internação e aumento sem significância estatística das taxas de mortalidade, que podem estar relacionados à exposição ambiental aos agrotóxicos.

Ainda sobre a exposição aos agrotóxicos em regiões do Nordeste brasileiro, estudo realizado no Ceará analisou dados referentes à morbimortalidade por câncer infanto-juvenil, entre os anos 2000 e 2012, e concluiu que há uma coincidência entre o maior número de casos de câncer infanto-juvenil e as microrregiões em que foram implementados os polos de irrigação agrícola, nos quais há um uso intensivo de agrotóxicos (Barbosa et al., 2019).

Sobre a taxa média de câncer infanto-juvenil, nos anos 2017 e 2018, no Brasil, os valores encontrados foram de 43 para cada 1.000 .000 de habitantes. Nos Cerrados, foi de 45,2 para cada 1.000 .000 de habitantes, conforme apresentado na Figura 12.

Apesar do número crescente de intoxicações agudas e crônicas por agrotóxicos no Brasil, constata-se a ineficiência do governo brasileiro, principalmente por meio de políticas públicas na área da saúde, para enfrentar essa grave problemática. O Sistema Único de Saúde (SUS) não tem implementado ações efetivas, no âmbito da vigilância em saúde, para evitar o surgimento de novos casos de intoxicações, e no âmbito assistencial, para garantir

\footnotetext{
${ }^{15}$ Nota da ABRASCO sobre o herbicida glifosato disponível em: <https://www.abrasco.org.br/site/wp-content/uploads/2019/06/Parecer-tecnico-glifosato-GTSA-26_06_2019-1.pdf>. Acesso em: jan. 2021.
} 
o acesso das pessoas adoecidas a um acompanhamento adequado. Ao contrário, por dimensões que envolvem desde o despreparo dos profissionais de saúde para lidar com essas necessidades específicas; a precarização do trabalho em saúde; o subfinanciamento do sistema de saúde, principalmente na área da Atenção Primária à Saúde (APS); até os contextos regionais e locais onde são perpetuadas a violência engendrada pelo agronegócio nos territórios em que possuem uma importante influência

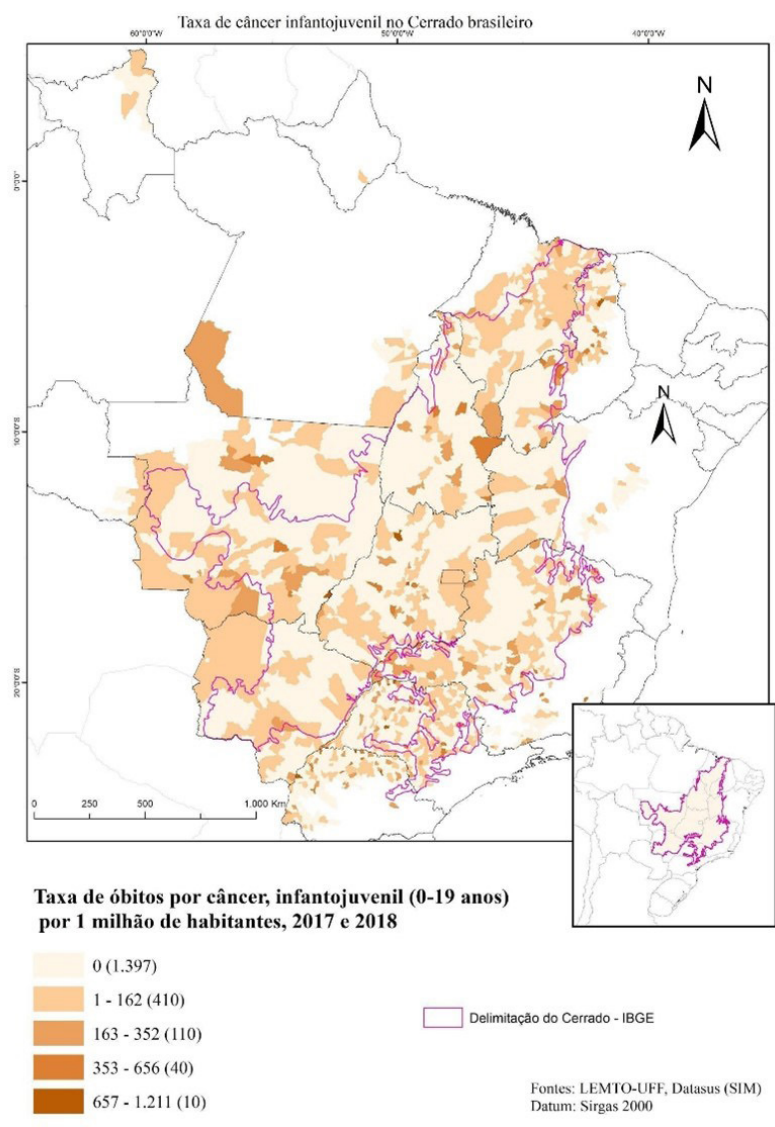

FIGURA 12 - Taxa média de câncer infanto-juvenil, em municípios dos Cerrados brasileiros, ano 2018. política e econômica, muitos desses casos são completamente invisibilizados, propagando-se um ciclo perverso de ausência de suspeita, ausência de diagnóstico e, consequentemente, ausência de notificação (Rigotto \& Aguiar, 2015).

\section{Considerações finais}

A despeito dos negacionistas, há evidências suficientes de que estamos diante de um acontecimento para o qual não temos como fechar os olhos e voltar as costas: a modernidade capitalista colocou em risco a estabilidade do ecossistema global, impondo uma situação limítrofe para a humanidade, em que a sustentação mais fundamental da Vida - água, ar, solo, clima, biodiversidade, sementes - encontra-se já profundamente comprometida. Fomos capazes de demarcar uma nova época geológica, o Antropoceno, para os que conferem centralidade à ação humana, ou o Capitaloceno, que enfatiza o "câmbio no processo histórico em curso do capitalismo, que incorporou as condições da natureza num projeto específico de reorganizar o mundo material" (Barcelos, 2019).

A ideologia do desenvolvimento, com seus postulados de dominação da natureza, espoliação das colônias e exploração do trabalho humano e das mulheres para o crescimento ilimitado da produção e do consumo, deixou-nos esse trágico legado sem ter cumprido suas promessas de bem estar, e, ao contrário, produzindo profundas desigualdades e injustiças, articuladas pelas opressões de classe, raça/ etnia e gênero.

Nos Cerrados - esse precioso bioma, que deveria receber todo o nosso cuidado em tempos de colapso socioambiental -, cinco décadas de "desenvolvimento" estão produzindo o Ecocídio. Como 
vimos, mais de 110 milhões de hectares do bioma estão ocupados pelo agronegócio, quando se soma a área plantada para produzir $75 \%$ das commodities soja-cana-milho-algodão cultivadas no Brasil e as áreas de pastagem destinadas à produção de carne bovina. Além de destruir mais da metade da rica e diversificada vegetação nativa -29 milhões de hectares desmatados apenas em 2019/20 -, a agricultura irrigada exaure as águas superficiais e subterrâneas para alimentar as áreas equipadas com pivôs centrais, que se concentram nos Cerrados $(91,8 \%)$, levando, por exemplo, à redução de $49,2 \%$ na alimentação do Rio São Francisco pelo fluxo de base do Sistema Aquífero Urucuia em 35 anos. Isso sem mencionar o número cada vez maior de rios com o balanço hídrico em situação muito crítica, ou seja, com mais de $40 \%$ de sua vazão comprometida, além do crescente número de rios mortos.

Ademais, derramam sobre a terra - muitas vezes grilada - mais de 600 milhões de litros de venenos por ano, concentrando $73,5 \%$ do total de agrotóxicos consumidos no país em 2018, com graves impactos sobre a saúde de seus povos. Se a taxa média nacional de intoxicação exógena em 2016 e 2017 foi de 6,8 casos para cada 100.000 habitantes (em que pesem o subdiagnóstico e o subregistro), para os municípios dos Cerrados, ela foi de 8,5. Também há mais casos de câncer infanto-juvenil nos Cerrados ( 45,2 por 1 milhão de habitantes) que no país como um todo (43 por 1 milhão de habitantes). É provável que essa concentração de danos à saúde inclua também os agravos relacionados à insegurança alimentar e hídrica, como a desnutrição e o diabetes, decorrente da perda da terra e/ou das condições para cultivá-la. E as manifestações clínicas do sofrimento psicossocial derivado da desterritorialização e da insegurança quanto ao futuro. E também as repercussões das violências sobre o processo saúde-doença, sejam os acidentes de trabalho na agricultura mecanizada, sejam as violências que encontram nas cidades aqueles que foram submetidos aos processos de migração compulsória, sejam as violências contra as mulheres, consignadas na desestruturação das famílias, na exploração sexual, na sobrecarga de trabalho.

Assim, as informações e análises trazidas neste texto dão base para a compreensão dos Cerrados enquanto zona de sacrificio do desenvolvimento brasileiro, em que Natureza e Povos são saqueados para garantir a acumulação de poucos, muito poucos. Se ecocídio é "o sério dano, destruição ou perda de um ou mais ecossistemas, em um determinado território, seja por causas humanas ou por outras causas, cujo impacto causa uma diminuição severa nos benefícios ambientais dos quais os habitantes desse território desfrutavam"16, consideramos que as informações e análises aqui reunidas sobre as consequências da expansão do agronegócio para o bioma e seus povos, especialmente no que toca às águas e aos agrotóxicos, caracterizam dimensões do Ecocídio em curso, concretizado como produto moderno-colonial racista nos Cerrados.

Considerando que não é possível, nem ético, nem justo, prosseguir nesse caminho que atropela as possibilidades de futuro dos seres humanos e não humanos dos Cerrados e dos biomas do subcontinente sul-americano que interagem com eles, é preciso estender o olhar em busca de pistas. Olhar e ver os povos dos Cerrados enquanto guardiões da imensa riqueza desse vasto território. Pelo menos desde 1730, quando o Quilombo Quariterê, no Mato Grosso,

\footnotetext{
${ }^{16}$ Estatuto do Tribunal Permanente dos Povos (2018), disponível em: <http://permanentpeoplestribunal.org/estatuto/?lang=es>. Acesso em:
} jan. 2021. 
onde vivia Tereza de Benguela, já abrigava negros e indígenas para viverem a seu modo, plantando milho, mandioca, feijão e banana, tomando suas decisões em um parlamento comunitário, transformando as armas lançadas contra eles em ferramentas para o cultivo da terra e resistindo aos soldados até ${ }^{17}$.

Herdeiras e herdeiros de Tereza seguem hoje cuidando dos Cerrados, compartilhando seus conhecimentos ancestrais, buscando formas de seguir em seus modos de vida e lutando em defesa de seus territórios, apesar dos 32 assassinatos em 2019 (CPT, 2020).

A elas e eles se somam movimentos, entidades e redes como a Campanha Nacional em Defesa do Cerrado, a Campanha Permanente contra os Agrotóxicos e pela Vida ${ }^{18}$, a Comissão Pastoral da Terra ${ }^{19}, \mathrm{o}$ Greenpeace ${ }^{20}$, a ActionAid ${ }^{21}$, a Fase ${ }^{22}$ e muitos outros.

Contribuem também pesquisadores como Altair Sales Barbosa, Carlos Eduardo Mazzetto Silva, Carlos Walter Porto-Gonçalves, Wanderlei Pignati e Débora Fernandes Calheiros - inspirações para todos e todas nós do mundo acadêmico, na perspectiva de uma ciência solidária e emancipatória.

E não nos esqueçamos da potência da arte, expressa na criação daquele que universalizou o sertão e suas veredas, Guimarães Rosa:

O senhor vê: existe cachoeira; e pois? Mas cachoeira é barranco de chão, e água se caindo por ele, retombando; o senhor consome essa água, ou desfaz o barranco, sobra cachoeira alguma? Viver é negócio muito perigoso $[\ldots]$.

\section{Referências}

ANA - Agência Nacional de Águas (Brasil). Atlas irrigação: uso da água na agricultura irrigada. 2017. Disponível em: $<$ https://arquivos.ana.gov.br/imprensa/publicacoes/AtlasIrrigacao-UsodaAguanaAgriculturaIrrigada.pdf $>$. Acesso em: out. 2020.

ANA - Agência Nacional de Águas (Brasil). Conjuntura dos recursos hídricos no Brasil 2019: informe anual. 2019a. Disponível em: <http://conjuntura.ana.gov.br/static/media/ conjuntura-completo.bb39ac07.pdf $>$ Acesso em: set. 2020.

ANA - Agência Nacional de Águas (Brasil). Levantamento da agricultura irrigada por pivôs centrais no Brasil. 2019b. Disponível em: <https://www.ana.gov.br/noticias/ana-e-embrapa-identificam-forte-tendencia-de-crescimento-da-agricultura-irrigada-por-pivos-centrais-no-brasil/ana_levantamento-da-agricultura-irrigada-por-pivos-centrais_2019.pdf $>$. Acesso em: set. 2020.

ActionAid; RSJDH - Rede Social de Justiça e Direitos Humanos. Impactos da expansão do agronegócio no Matopiba: comunidades e meio ambiente. 2017. Disponível em: $<\mathrm{http}: / /$ actionaid.org.br/publicacoes/impactos-da-expansao-do-agronegocio-no-matopiba-comunidades-e-meio-ambiente-2/>. Acesso em: jul. 2020.

Acselrad, H. Justiça ambiental e construção social do risco. Desenvolvimento e Meio Ambiente, 5, 49-60, 2002. doi: 10.5380/dma.v5i0.22116

Acselrad, H. O conhecimento do ambiente e o ambiente do conhecimento: anotações sobre a conjuntura do debate sobre vulnerabilidade. Em Pauta, 32(11), 115-129, 2013. doi: 10.12957/rep. 10158

Aguiar,A.C.P. Más-formações congênitas, puberdade precoce

\footnotetext{
${ }^{17}$ Mais informações disponíveis em: <https://www.ufrb.edu.br/bibliotecacecult/noticias/220-tereza-de-benguela-a-escrava-que-virou-rainha-e-liderou-um-quilombo-de-negros-e-indios>. Acesso em: jan. 2021.

${ }^{18}$ Mais informações disponíveis em: <https://contraosagrotoxicos.org/>. Acesso em: jan. 2021.

${ }^{19}$ Mais informações disponíveis em: <https://www.cptnacional.org.br>. Acesso em: jan. 2021.

${ }^{20}$ Mais informações disponíveis em: <https://greenpeace.org >. Acesso em: jan. 2021.

${ }^{21}$ Mais informações disponíveis em: $<$ https://actionaid.org>. Acesso em: jan. 2021.

${ }^{22}$ Mais informações disponíveis em: <https://fase.org.br>. Acesso em: jan. 2021.
} 
e agrotóxicos: uma herança maldita do agronegócio para a Chapada do Apodi (CE). Fortaleza, Dissertação (Mestrado em Saúde Coletiva) - UFC, 2017.

Alves, V.E.L. Mobilização e modernização no Cerrado piauiense: formação territorial no império do agronegócio. São Paulo, Tese (Doutorado em Geografia). USP, 2006.

Barbosa, A.S. Cerrados: biodiversidade e pluralidade. Blog Cerrado: do científico ao poético. Goiânia, 8 de novembro de 2008. Disponível em: <http://altairsalesbarbosa.blogspot. com/2008/11/cerrado-biodiversidade-e-pluralidade.html $>$. Acesso em: jun. 2020.

Barbosa, A.S. O Cerrado está extinto e isso leva e isso leva ao fim dos rios e dos reservatórios de água. [Entrevista concedida a] Elder Dias. Sul21, 15 de novembro de 2014. Disponível em: $<$ https://www.sul21.com.br/ultimas-noticias/geral/2014/11/ altair-sales-barbosa-o-cerrado-esta-extinto-e-isso-leva-ao-fim-dos-rios-e-dos-reservatorios-de-agua/>. Acesso em: jul. 2020.

Barbosa, A.S. Viva a agricultura brasileira, mas ainda não aprendemos a lição. Jornal Opção, 29 de junho de 2020. Disponível em: <https://www.jornalopcao.com.br/colunas -e-blogs/imprensa/viva-a-agricultura-brasileira-mas-ainda-nao-aprendemos-a-licao-264607/ >. Acesso em: jul. 2020.

Barbosa, I. M.; Sales, D. S.; Arregi, M. U.; Rigotto, R. M. Câncer infantojuvenil: relação com os polos de irrigação agrícola no estado do Ceará, Brasil. Ciênc. Saúde Coletiva, 24(4), 1563-1570, 2019. doi: https://doi.org/10.1590/141381232018244.06662017 .

Barcelos, E. Antropoceno ou Capitaloceno: da simples disputa semântica à interpretação histórica da crise ecológica global. Revista Iberoamericana de Economia Ecológica, 31(1), 1-17, 2019. Disponível em: <https://redibec.org/ojs/index.php/ revibec/article/view/356>

Belpomme, D.; Irigaray, P.; Hardell, L.; Clapp, R.; Montagnier, L.; Epstein, S.; Sasco, A.J. The multitude and diversity of environmental carcinogens. Environ Res. 105(3), 414-429, 2007. doi: 10.1016/j.envres.2007.07.002

Bochner, R.; Freire, M.M. Análise dos óbitos decorrentes de intoxicação ocorridos no Brasil, de 2010 a 2015, com base no Sistema de Informação sobre Mortalidade (SIM). Ciência \& Saúde Coletiva, 25(2),761-772, 2020. doi: 10.1590/141381232020252.15452018
Bonfim, J. S.; Vicente, J. S. Territorialização do agronegócio e apropriação das águas no Cerrado baiano. In: Geografia das redes de mobilização social na América Latina (SINGA). Curitiba, nov. 2017. Disponível em: $<$ https://singa2017.files. wordpress.com/2017/12/gt10_1506906864_arquivo_trabalhocompletosinga2017.pdf $>$. Acesso em: jun. 2020.

Brandão, C.R. A comunidade tradicional. In: Costa, J.B.A.; Luz, C. (Orgs.). Cerrados, Gerais, Sertão: Comunidades tradicionais dos sertões Roseanos. Montes Claros: Intermeios, p.347-361, 2010. Disponível em: <http://nupaub.fflch.usp.br/ sites/nupaub.fflch.usp.br/files/a\%20comunidade $\% 20 \operatorname{trad} 160$. pdf $>$. Acesso em: jun. 2020.

Brender, J.D.; Felkner, M.; Suarez, L.; Canfield, M.A.; Henry, J.P. Maternal pesticide exposure and neural tube defects in Mexican Americans. Ann Epidemiol., 20,16-22, 2010. doi: 10.1016/j.annepidem.2009.09.011

Carvalho, G.S. Impacto do agronegócio na dinâmica hídrica da bacia hidrográfica do rio Corrente: pegada hídrica e percepção. Brasília, Dissertação (Mestrado em Desenvolvimento Sustentável) - UNB, 2019.

Carvalho, I. Fazenda símbolo de grilagem sofre derrota "emblemática" e perde área para geraizeiros. Brasil de Fato, São Paulo, 10 de julho de 2020. Disponível em: <https://www. brasildefato.com.br/2020/07/10/fazenda-simbolo-de-grilagem-sofre-derrota-emblematica-e-perde-area-para-geraizeiros $>$. Acesso em: jun. 2020.

CBHSF - Comitê Da Bacia Hidrográfica do Rio São Francisco. O Velho Chico está sendo soterrado. 2020. Disponível em: <https://cbhsaofrancisco.org.br/noticias/novidades/ revista-6-o-velho-chico-esta-sendo-soterrado/>. Acesso em: jul. 2020.

Chagas, D. Queremos nossos gerais livre de violência. 2019. Disponível em: $<$ https://redeCerrados.org.br/queremos-nosso-gerais-livre-de-violencias/>. Acesso em: ago. 2020.

Chevrier, C.; Limon, G.; Monfort, C. et al. Urinary biomarkers of prenatal atrazine exposure and adverse birth outcomes in the PELAGIE birth cohort. Environ Health Perspect 119, 1034-1041, 2011. doi: 10.1289/ehp.1002775

Coletivo Brasileiro de Pesquisadores da Desigualdade Ambiental. Desigualdade ambiental e acumulação por espoliação: O que está em jogo na questão ambiental? E-cadernos $C E S$ 
(Online), v. 17, p. 164-183, 2013.

Costa, V.I.B.; Mello, M.S.C.; Friedrich, K. Exposição ambiental e ocupacional a agrotóxicos e linfoma não Hodgkin. Saúde em Debate. 41(112), 49-62, março de 2017. doi: 10.1590/0103-1104201711205

CPT - Comissão Pastoral da Terra. Conflitos no campo: Brasil 2019. 2020. Disponível em: <https://www.cptnacional.org. br/publicacoes-2/destaque/5167-conflitos-no-campo-brasil-2019>. Acesso em: abr. 2020.

Cremonese, C.; Freire, C.; Camargo, A. M.; Lima, J. S.; Koifman, S.; Meyer, A. Pesticide consumption, central nervous system and cardio-vascular congenital malformations in the South and Southeast region of Brazil. Int. J. Occup. Med. Environ. Health. 27(3), 474-486, 2014. doi: 10.2478/ s13382-014-0269-5

Cunha, T.B. Do Oculto ao Visivel: Terra-Água-Trabalho e o Conglomerado Territorial do Agrohidronegócio no Oeste da Bahia. Presidente Prudente, Tese (Doutorado em Geografia) - Unesp, 2017.

Dutra, L.S.; Ferreira, A.P. Tendência de malformações congênitas e utilização de agrotóxicos em commodities: um estudo ecológico. Saúde em Debate, 43 (121), 390-405, 2019. doi: 10.1590/0103-1104201912108

Delgado, G. Do capital financeiro à economia do agronegócio . Mudanças cíclicas em meio século (1965-2012). Porto Alegre: Editora da UFRGS, 2012.

Frederico, S. Agricultura científica globalizada e fronteira agrícola moderna no Brasil. Confins, 17, 2013. doi: 10.4000/ confins.8153.

Frederico, S.; Almeida, M.C. Capital financeiro, land grabbing e a multiescalaridade na grilagem de terra na região do MATOPIBA. Revista NERA. 22(47), 123-147, 2019. doi: 10.47946/rnera.v0i47.6268

Freire, M.H.S.; Barros, A.P.M.M.; Andrade, L.; et al., Análise geoespacial dos nascimentos com anomalias congênitas, Paraná, 2008-2015: estudo ecológico. Rev Bras Enferm, 73(3), 1-9, 2020. doi: http://dx.doi.org/10.1590/0034-7167-2018-0741

Fiocruz - Fundação Oswaldo Cruz. Coleção Saúde, Ambiente e Sustentabilidade. Série Fiocruz Institucionais. Agrotóxicos e Saúde, Vol. 2. 2018. Disponível em: <https://portal.fiocruz. $\mathrm{br} /$ documento/colecao-saude-ambiente-e-sustentabilidade-capitulo-2-agrotoxicos>. Acesso em: ago. 2020.

Gemmillet, A; Gunier, R.B.; Bradman, A.; Eskenazi, B.; Harley, K.G. Residential proximity to methyl bromide use and birth outcomes in an agricultural population in California. Environ Health Perspect, 121, 737-743, 2013. doi: 10.1289/ ehp.1205682

Gonçalves, R.D.; Engelbrecht, B.Z.; Chang, H.K. Evolução da contribuição do Sistema Aquífero Urucuia para o Rio São Francisco, Brasil. Águas Subterrâneas, 32(1), 1-10, 2018. doi: 10.14295/ras.v32i1.28916

Greenpeace. Segure a linha: a expansão do agronegócio e a disputa pelo cerrado. 2018. Disponível em: <https://www. greenpeace.org/brasil/publicacoes/relatorio-segure-a-linha/> Acesso em: dez. 2020

Gudynas, E. Diez tesis urgentes sobre el nuevo extractivismo: contextos y demandas bajo el progresismo sudamericano actual. In: Extractivismo, política y sociedade (vários autores). Quito: CAAP (Centro Andino de Acción Popular) e CLAES (Centro Latino Americano de Ecología Social), p. 187-225, 2009.

Harvey, D. A produção capitalista do espaço. São Paulo: Annablume, 2005.

IBGE - Instituto Brasileiro de Geografia e Estatística. Sistema IBGE de Recuperação Automática - SIDRA. Produção Agrícola Municipal (PAM). Informações sobre culturas temporárias e permanentes, 2018. 2020. Disponível em: $<$ https://sidra. ibge.gov.br/pesquisa/pam/tabelas $>$. Acesso em jun. 2020.

Khoury, L. Nota Técnica 01/2018. Ministério Público do Estado da Bahia, NUSF-Núcleo de Defesa da Bacia do São Francisco, 2018. Disponivel em: $<$ https://www.mpba. $\mathrm{mp}$. br/conteudo/n\%C $3 \%$ Bacleo-de-defesa-da-bacia-do-s\%C3\%A3o-francisco-nusf $>$. Acesso em: jul. 2020

LAPIG - Laboratório de Processamentos de Imagens e Geoprocessamento de Imagens da Universidade Federal de Goiás (UFG). Atlas Digital das Pastagens Brasileiras. Disponível em: $<$ https://www.lapig.iesa.ufg.br/lapig/index.php/produtos/ atlas-digital-das-pastagens-brasileiras $>$. Acesso em: jul. 2020.

Lander, E. (org). A colonialidade do saber: eurocentrismo e ciências sociais. Perspectivas latinoamericanas. Colección Sur Sur, CLACSO. Buenos Aires, Argentina, 2005. 
Magalhães, J. Comunidades de Fundo e Fecho de Pasto, espaços coletivos onde os rebanhos são criados soltos. 2018. Disponível em: <https:/www.abracoguarapiranga.org.br/ single-post $/ 2018 / 04 / 15 /$ Correntina-as-Guerras-da- $\%$ C3\%81gua-chegam-ao-Brasil >. Acesso em: ago. 2020.

Makelarski, J. A.; Romitti, P. A.; Rocheleau, C. M.; et al. Maternal periconceptional occupational pesticide exposure and neural tube defects. Birth Defects Res A Clin Mol Teratol. 100, 877-886, 2014. doi: 10.1002/bdra.23293

MAPA - Ministério da Agricultura, Pecuária e Abastecimento. Projeções do agronegócio : Brasil 2016/17 a 2026/27. 2017. Disponível em: $<$ https://www.gov.br/agricultura/pt-br/assuntos/politica-agricola/todas-publicacoes-de-politica-agricola/ projecoes-do-agronegocio/projecoes-do-agronegocio-2017-a-2027-versao-preliminar-25-07-17.pdf/view>. Acesso em: mai. 2020

Mapbiomas. Dados do Relatório Anual de Desmatamento, 2019. São Paulo, 49p., 2020. Disponível em: $<$ http://alerta.mapbiomas.org/relatorios\#: :text=Mais $\% 20 \mathrm{de} \% 2060 \% 25 \% 20$ da $\% 20 \%$ C $3 \%$ A 1 rea,e $\% 20$ Pampa $\% 20(642 \% 20$ ha) $)$. Acesso em: dez. 2020.

Mazzetto Silva, C. E. Ordenamento territorial no Cerrados brasileiro. Desenvolvimento e Meio Ambiente, 19, 89-109, 2009. doi: 10.5380/dma.v19i0.16407

MMA - Ministério do Meio Ambiente (Brasil). Caderno da Região Hidrográfica do Tocantins-Araguaia. 2006. Disponível em: $<$ http://www.terrabrasilis.org.br/ecotecadigital/index. php/estantes/gestao/695-caderno-da-regiao-hidrografica-do-tocantins-araguaia >. Acesso em: jul. 2020.

MMA - Ministério do Meio Ambiente. Plano de Ação para Prevenção e Controle do Desmatamento e das Queimadas no Cerrados (PPCerrados). Brasília: MMA, 2009.

Mostafalou, S.; Abdollahi, M. Pesticides: an update of human exposure and toxicity. Archives of Toxicology. 91(2), 549-599, 2016. doi:10.1007/s00204-016-1849-x

Mota, J.; Motoki, C. Comunidades de fundo e fecho de pasto. Repórter Brasil, 3 de julho de 2018. Disponível em: $<$ https:// reporterbrasil.org.br/comunidadestradicionais/fundo-e-fecho-de-pasto-da-bahia/>. Acesso em: out. 2020.

Moura, L. T. R.; Bedor, C. N. G.; Lopez, R. V. M.; et al. Expo- sição ocupacional a agrotóxicos organofosforados e neoplasias hematológicas: uma revisão sistemática. Rev. bras. Epidemiol. 23, 2020. doi: 10.1590/1980-549720200022

MS - Ministério da Saúde. Departamento de Informática. DATASUS. Informações de Saúde (TABNET), 2020. Disponível em: <http://www2.datasus.gov.br/DATASUS/index.php>. Acesso em: jul. 2020.

Neves, P.D.M.; Mendonça, M.R.; Bellini, M.; Pôssas, I.B. Intoxicação por agrotóxicos agrícolas no estado de Goiás, Brasil, de 2005-2015: análise dos registros nos sistemas oficiais de informação. Ciência \& Saúde Coletiva, 25(7), 2743-2754, 2020. doi:10.1590/1413-81232020257.09562018

Okuyama, J.H.H.; Galvão, T.F.; Silva, M.T. Intoxicações e fatores associados ao óbito por agrotóxicos: estudo caso controle, Brasil, 2017. Rev Bras Epidemiol., 23,1-13, 2020. doi: 10.1590/1980-549720200024

Oliveira, A.U. Reforma agrária, grilagem das terras públicas e a luta pela terra e território no Brasil. In: Universidad de Havana (Org.). Por una América Latina unida y sostentable. Havana: Distribuidora Nacional ICAIC, p. 1-15, 2015. Disponível em: $<$ http://observatoriogeograficoamericalatina.org. $\mathrm{mx} /$ egal15/Geografiasocioeconomica/ Geografiaagraria/04. pdf>. Acesso em: jul. 2020.

OMS - Organização Mundial Da Saúde. IARC Monographs - 112. International Agency for Research on Cancer. 2015. Disponível em: <https://monographs.iarc.fr/wp-content/ uploads/2018/06/mono112-10.pdf > . Acesso em: jun. 2020.

Pignati, W.A.; Lima, F.; Lara, S.S. et al. Distribuição espacial do uso de agrotóxicos no Brasil: uma ferramenta para a Vigilância em Saúde. Ciência \& Saúde Coletiva, 22(10), 32813293, 2017. doi: 10.1590/1413-812320172210.17742017

Pluth, T.B.; Zanini, L.A.G.; Battisti, I.D.E. Exposição a pesticidas e câncer: uma revisão integrativa da literatura. Saúde em Debate, 43(122):906-924, setembro de 2019. Epub. 25, 2019. doi: $10.1590 / 0103-1104201912220$

Porto-Gonçalves, C.W. "Navegar é preciso; viver não é preciso": estudo sobre o Projeto de Perenização da Hidrovia dos Rios das Mortes, Araguaia e Tocantins. Terra Livre, 15, 167-213, 2000. Disponível em: <https://www.agb.org.br/ publicacoes/index.php/terralivre/article/view/367/349>. 
Porto-Gonçalves, C.W. Dos Cerrados e de suas riquezas: de saberes vernaculares e de conhecimento científico. Orgs. (Diana Aguiar/Fase e Valéria Pereira dos Santos/CPT. Rio de Janeiro e Goiânia: Fase e CPT, 2019.

Porto-Gonçalves; C.W.; Chagas, S.B. Os pivôs da discórdia e a digna raiva: uma análise dos conflitos por terra, água $\mathrm{e}$ território em Correntina-BA. Bom Jesus da Lapa: Gráfica e Editora Bom Jesus, 2019.

Projeto Nova Cartografia Social Da Amazônia. Série: Povos e Comunidades Tradicionais do Brasil Central. Fascículo 01: Povo Indígena Kanela do Araguaia. Manaus, 2009.

Queiroz, P.R.; Lima, K.C.; Oliveira, T.C. et al. Sistema de Informação de Agravos de Notificação e as intoxicações humanas por agrotóxicos no Brasil. Rev Bras Epidemiol. 22, 1-10, 2019. doi: 10.1590/1980-549720190033

Rigotto, RM; Aguiar, ACP. Invisibilidade ou invisibilização dos efeitos crônicos dos agrotóxicos à saúde? Desafios à ciência e às políticas públicas. In: Observatório Internacional de Capacidades Humanas, Desenvolvimento e Políticas Públicas: Estudos e Análises 2. Brasília: UnB/ObservaRH/ Nesp-Fiocruz/Nethis, 2015. Pp. 47-90.

Rodrigues, D. B. O projeto Rio Formoso e a reprodução ampliada do capital no entorno da Ilha do Bananal - TO: concentração da riqueza, exclusão e resistência. Palmas, Dissertação (Mestrado em Geografia ) - UFTO, 2013.

Sales, L. T. Território Retireiro em disputa: cerca que divide e a perda do território de uso comunal dos Retireiros e Retireiras do Araguaia no Mato Grosso. Brasilia, Dissertação (Mestrado em Desenvolvimento Sustentável) - UNB, 2018.

Santos, M.; Glass, V. Atlas do agronegócio: fatos e números sobre as corporações que controlam o que comemos. 2018. Disponível em: $<$ https://br.boell.org/sites/default/files/ atlas_agro_final_06-09.pdf $>$. Acesso em: jul. 2020.

Seplan - Secretaria do Planejamento e Orçamento. Perfil do Agronegócio Tocantinense. 2016. Disponível em: <http:// www.sefaz.to.gov.br/desenvolvimento-regional/estudos-e-projetos/perfil-do-agronegocio-tocantinense/>. Acesso em: dez. 2020.

Silva, C.E.M. O Cerrados em disputa: apropriação global e resistências locais. Brasília: CONFEA/CREA, 2009.
Silva, S. R. G.; Martins, J. L.; Seixas, S.; Silva, D. C. G.; Lemos, S. P. P.; Lemos, P. V. B. Defeitos congênitos e exposição a agrotóxicos no Vale do São Francisco. Rev. Bras. Ginecol. Obstet. 33(1), 20-26, 2011. doi: 10.1590/S010072032011000100003

Silva, D.O.; Ferreira, M.J.M.; Silva, S.A.; Santos, M.A.; Hoffmann-Santos, H.; Silva, A.M.C.; Exposure to pesticides and acute intoxication in a region of intense agricultural production in Mato Grosso, Brazil, 2013. Epidemiol. Serv. Saude, Brasília, 28(3), 2019. doi: 10.5123/s1679-49742019000300013

Silva, M.G.P.; Bedor, C.N.G.; Alencar, K.M.S.A.; Curado, M.P.; Moura, L.T.R. Tendências da morbimortalidade por câncer infantojuvenil em um pólo de fruticultura irrigada. Cad. Saúde Colet.26(1),38-44, 2018. doi: 10.1590/1414$462 \times 201800010477$

Silva, P.R.F. A expansão agrícola no Cerrado e seus impactos no ciclo hidrológico: estudo de caso na região do MATOPIBA. Brasília, Dissertação (Mestrado em Desenvolvimento Sustentável) - UNB, 2020.

Siqueira, M.T.; Braga, C.; Cabral-Filho, J. E.; Augusto, L. G. Da S.; Figueiroa, J. N.; Souza, A. I. Correlation Between Pesticide Use in Agriculture and Adverse Birth Outcomes in Brazil: an Ecological Study. Bulletin Of Environmental Contamination And Toxicology, 84 (6), 647-651, 2010. doi: 10.1007/s00128-010-0027-8

Svampa, M. Extrativismo neodesenvolvimentista e movimentos sociais: um giro ecoterritorial rumo a novas alternativas? In: Dilger, G.; Lang, M.; Pereira Filho, J. (Orgs.). Descolonizar o imaginário: debates sobre pós-extrativismo e alternativas ao desenvolvimento. São Paulo: Fundação Rosa Luxemburgo, 2016.

Tatemoto, R. Em Correntina(BA), população se manifesta contra captação empresarial de água. Brasil de Fato, 01 dezembro de 2017. Disponível em: <https://www.brasildefato.com. br/2017/12/01/em-correntina-ba-populacao-se-manifesta-contra-a-captacao-empresarial-de-agua $>$. Acesso em ago. 2020.

Ueker, M.E.; Silva, V.M.; Moi, G.P.; Pignati, W.A.; Mattos, I.E.; Silva, A.M.C. Parenteral exposure to pesticides and occurrence of congenital malformations: hospital-based case-control study. BMC Pediatrics 16(1), 2-7, 2016. doi: 10.1186/s12887-016-0667-x 